Published in final edited form as:

Sci Immunol. 2019 July 05; 4(37): . doi:10.1126/sciimmunol.aav8995.

\title{
Human CD4+CD103+ cutaneous resident memory T cells are found in the circulation of healthy subjects
}

\author{
M. M. Klicznik ${ }^{1, \dagger}$, P. A. Morawski ${ }^{2, \dagger}$, B. Höllbacher ${ }^{1,2}$, S. R. Varkhande ${ }^{1}$, S. Motley ${ }^{2}$, L. Kuri- \\ Cervantes $^{3}$, E. Goodwin ${ }^{3}$, M. D. Rosenblum ${ }^{4}$, S. A. Long ${ }^{2}$, G. Brachtl ${ }^{5}$, T. Duhen ${ }^{2}$, M.R. \\ Betts $^{3}$, D. J. Campbell $2,6,{ }^{*}, \ddagger$, I. K. Gratz ${ }^{1,2,7,{ }^{*}, \neq}$ \\ ${ }^{1}$ Department of Biosciences, University of Salzburg, Salzburg, Austria. \\ ${ }^{2}$ Benaroya Research Institute, Seattle WA 98101, USA. \\ ${ }^{3}$ Department of Microbiology, Perelman School of Medicine, University of Pennsylvania, \\ Philadelphia, PA 19104. \\ ${ }^{4}$ Department of Dermatology, University of California, San Francisco CA 94143, USA. \\ ${ }^{5}$ Experimental \& Clinical Cell Therapy Institute, Spinal Cord \& Tissue Regeneration Center, \\ Paracelsus Medical University, Salzburg, Austria. \\ ${ }^{6}$ Department of Immunology, University of Washington School of Medicine, Seattle WA 98109, \\ USA.
}

${ }^{7}$ EB House Austria, Department of Dermatology, University Hospital of the Paracelsus Medical University, Salzburg, Austria.

\section{Abstract}

Tissue-resident memory $\mathrm{T}$ cells $\left(\mathrm{T}_{\mathrm{RM}}\right)$ persist locally in non-lymphoid tissues where they provide front-line defense against recurring insults. $\mathrm{T}_{\mathrm{RM}}$ at barrier surfaces express the markers CD103 and/or CD69, which function to retain them in epithelial tissues. In humans, neither the long-term migratory behavior of $\mathrm{T}_{\mathrm{RM}}$ nor their ability to re-enter the circulation and potentially migrate to distant tissue sites have been investigated. Using tissue explant cultures, we found that $\mathrm{CD} 4{ }^{+} \mathrm{CD} 69^{+} \mathrm{CD} 103^{+} \mathrm{T}_{\mathrm{RM}}$ in human skin can downregulate $\mathrm{CD} 69$ and exit the tissue. Additionally, we identified a skin-tropic $\mathrm{CD} 4^{+} \mathrm{CD} 69^{-} \mathrm{CD} 103^{+}$population in human lymph and

\footnotetext{
"Corresponding authors: campbell@benaroyaresearch.org; iris.gratz@sbg.ac.at.

$\dagger$ First authors contributed equally

\#Last authors contributed equally

Author contributions: M.M.K., P.A.M., B.H., S.R.V., T.D., D.J.C. and I.K.G. designed the experiments and participated in the statistical analysis of the data; M.M.K., M.D.R. and I.K.G. developed xenografting methods; M.M.K., P.A.M., B.H., S.R.V., S.M. and T.D. performed experiments; B.H. performed computational analysis; L.K-C. and E.G. performed analysis of TDL samples, M.R.B. planned and supervised the analysis of TDL samples, S.A.L. helped develop the CyTOF panels; G.B. helped set up the sort panels; D.J.C. and I.K.G. wrote the manuscript; M.M.K., P.A.M., B.H., S.R.V., S.M., T.D. and M.D.R. reviewed and edited the paper; D.J.C. and I.K.G. supervised the project.

Competing interests: MMK and IKG are inventors on a pending patent application covering use of the skin humanized mouse model (European file number EP18168258; US file number US16389821). The other authors declare that they have no competing interests.

Data and materials availability: The complete RNA-seq data is available from the Gene Expression Omnibus under accession number GSE131770. Pairwise comparisons between T cell populations are included in Table S2. The CyTOF data is available at flowrepository.org under accession number FR-FCM-Z24B. HPV16 E6/E7-immortalized human keratinocyte and skin fibroblast cell lines are available to interested investigators through a Material Transfer Agreement with the University of Salzburg. All other data needed to evaluate the conclusions in the paper are present in the paper or the Supplementary Materials.
} 
blood that is transcriptionally, functionally and clonally related to the $\mathrm{CD} 4{ }^{+} \mathrm{CD} 69^{+} \mathrm{CD} 103^{+} \mathrm{T}_{\mathrm{RM}}$ population in the skin. Using a skin xenograft model, we confirmed that a fraction of the human cutaneous $\mathrm{CD} 4{ }^{+} \mathrm{CD} 103^{+} \mathrm{T}_{\mathrm{RM}}$ population can re-enter circulation, and migrate to secondary human skin sites where they re-assume a $\mathrm{T}_{\mathrm{RM}}$ phenotype. Thus, our data challenge current concepts regarding the strict tissue compartmentalization of $\mathrm{CD}^{+} \mathrm{T}$ cell memory in humans.

\section{One Sentence Summary:}

Human blood and lymph contain circulating $\mathrm{CD} 4{ }^{+} \mathrm{CD} 103^{+}$cutaneous resident memory $\mathrm{T}$ cells that can seed distant skin sites.

\section{Introduction}

T cell memory is compartmentalized into circulating and tissue-resident cell populations. Whereas circulating memory $\mathrm{T}$ cells continually patrol the body via the blood and lymphatics, tissue-resident memory $\mathrm{T}$ cell $\left(\mathrm{T}_{\mathrm{RM}}\right)$ populations establish residence in nonlymphoid organs, where they can provide potent recall responses (1). $T_{R M}$ populations at barrier surfaces such as the intestines, lungs, and skin are best defined by expression of the markers CD103 and/or CD69, which together function to restrict their recirculation and maintain tissue residence (2)(3). However, despite extensive studies there is no single-cell definition for $\mathrm{T}_{\mathrm{RM}}$. Instead the term $\mathrm{T}_{\mathrm{RM}}$ is used to describe a cell population within a tissue that is in substantial disequilibrium with cells in the circulation as measured by depletion, tissue-transplantation, or parabiosis studies (2)(4)(5).

$\mathrm{T}_{\mathrm{RM}}$ were first identified in the context of $\mathrm{CD} 8^{+} \mathrm{T}$ cell responses to infection (5)(6). Although cutaneous $\mathrm{CD} 8^{+} \mathrm{T}_{\mathrm{RM}}$ have been well-studied in the mouse, the behavior of CD4 ${ }^{+}$ memory $\mathrm{T}$ cells in mouse skin has been more controversial, with initial studies demonstrating that $\mathrm{CD} 4^{+} \mathrm{T}$ cells in the skin showed a more dynamic pattern of migration and recirculation than cutaneous $\mathrm{CD} 8^{+} \mathrm{T}$ cells, resulting in their equilibration with the circulating T cell pool (7)(8). However, skin inflammation or infection increased recruitment and retention of murine $\mathrm{CD} 4^{+} \mathrm{T}$ cells in the skin (8)(9), and in some cases led to the formation of sessile cutaneous $\mathrm{CD} 69^{+} \mathrm{CD} 103^{+} \mathrm{CD} 4^{+} \mathrm{T}$ cells with superior effector functions (10)(11). Within the skin, $\mathrm{T}_{\mathrm{RM}}$ are most abundant at the site of initial infection (11)(12). However, long-term maintenance of this biased distribution may pose a disadvantage for a large barrier organ like the skin where pathogen re-encounter at a secondary tissue site is possible.

As in experimental animals, human $\mathrm{CD}^{+} \mathrm{T}_{\mathrm{RM}}$ are generated in response to cutaneous microbes such as Candida albicans (11), but aberrantly activated or malignant $\mathrm{T}_{\mathrm{RM}}$ are implicated in skin diseases, including psoriasis and mycosis fungoides (13). However, in studying cutaneous $\mathrm{CD}^{+} \mathrm{T}_{\mathrm{RM}}$, reliance on animal models can be problematic due to fundamental structural differences in the skin in humans versus mice, and a lack of direct correspondence between cutaneous $\mathrm{T}$ cell populations in these species. For instance, whereas nearly all $\mathrm{CD} 4^{+} \mathrm{T}$ cells in murine skin are found in the dermis, the human epidermis is much thicker than in mice, and memory $\mathrm{CD}^{+} \mathrm{T}$ cells can be found throughout human skin, in both the dermal and the epidermal compartments (2). In human skin, most 
$\mathrm{CD}^{+} \mathrm{T}$ cells express CD69, and a fraction of these are also CD103 ${ }^{+}$. Moreover, studies following depletion of circulating T cells with anti-CD52 (alemtuzumab) demonstrated that the $\mathrm{CD} 103^{-}$and $\mathrm{CD} 103^{+} \mathrm{CD} 4^{+} \mathrm{CD} 69^{+} \mathrm{T}$ cell populations can persist locally in the skin in the absence of continual replacement by circulating cells (2), thereby defining them functionally as $\mathrm{T}_{\mathrm{RM}}$ populations.

Most human skin-resident memory $\mathrm{T}$ cells also express the cutaneous lymphocyte antigen (CLA), a glycan moiety that promotes skin homing of immune cells by acting as a ligand for E-selectin (14). CLA is also expressed by skin-tropic memory CD4 ${ }^{+} \mathrm{T}$ cells in human blood (15), but the clonal and functional relationship between the $\mathrm{CD}^{+} \mathrm{CLA}^{+} \mathrm{T}$ cells in blood and $\mathrm{T}_{\mathrm{RM}}$ populations in the skin are not well defined. To elucidate the relationship between $\mathrm{CD}^{+} \mathrm{CLA}^{+} \mathrm{T}$ cells in the blood and skin, we characterized circulating and cutaneous $\mathrm{T}$ cell populations, taking advantage of new technological tools including cytometry by time-offlight (CyTOF), transcriptional profiling of rare cell populations by RNA-sequencing, and a human skin xenograft mouse model. In tissue-explant and skin-xenograft mouse systems, we showed that $\mathrm{CD}^{+}{ }^{+} \mathrm{CLA}^{+} \mathrm{CD} 69^{+} \mathrm{CD} 103^{+} \mathrm{T}_{\mathrm{RM}}$ in human skin can downregulate $\mathrm{CD} 69$ and exit the tissue. Furthermore, we identified a distinct population of CD4 ${ }^{+} \mathrm{CLA}$ ${ }^{+} \mathrm{CD} 69^{-} \mathrm{CD} 103^{+} \mathrm{T}$ cells in human lymph and blood that shared phenotypic, functional and transcriptomic signatures with the $\mathrm{CD} 4{ }^{+} \mathrm{CLA}^{+} \mathrm{CD} 103^{+} \mathrm{T}_{\mathrm{RM}}$ population in the skin. TCR repertoire analysis confirmed the common clonal origins of the circulating and skin-resident $\mathrm{CD}^{+}{ }^{+} \mathrm{CLA}^{+} \mathrm{CD}_{103}{ }^{+}$cells. In skin-humanized mice we further showed that following exit from the skin, $\mathrm{CD}^{+}{ }^{+} \mathrm{CLA}^{+} \mathrm{CD} 103^{+} \mathrm{T}$ cells could migrate into distant human skin sites and regain CD69 expression upon re-entering the tissue. Thus, basal recirculation of the $\mathrm{CD}^{+}{ }^{+} \mathrm{CLA}^{+} \mathrm{CD} 103^{+} \mathrm{T}_{\mathrm{RM}}$ population can be detected in the steady state, and this can promote the spread of skin $\mathrm{T}_{\mathrm{RM}}$ throughout this large barrier tissue.

\section{Results}

\section{Cutaneous $\mathrm{CD}^{+}{ }^{+} \mathrm{CLA}+{ }^{+}{ }^{2} 103^{+} \mathrm{T}_{\mathrm{RM}}$ cells can downregulate $\mathrm{CD} 69$ and exit the skin}

Confirming prior analyses (2), we found that the vast majority of both $\mathrm{CD} 8^{+}$and $\mathrm{CD} 4^{+} \mathrm{T}$ cells in human skin expressed CD69, and a subset of CD69+ cells also expressed CD103 and thus had the phenotype of cutaneous $\mathrm{T}_{\mathrm{RM}}$ populations resistant to alemtuzumab-mediated depletion of circulating cells (Fig. 1, A and B; see Fig. S1 for representative T cell gating strategies from skin and blood). Consistent with their localization in the skin, most of these $\mathrm{CD} 9^{+} \mathrm{CD} 103^{+}$cells also expressed CLA, (Fig. 1C) (14). To directly assess the ability of different skin $\mathrm{T}$ cell populations to exit the tissue, we performed tissue explant cultures using human skin obtained from surgical samples. Despite high expression of CD69 in the tissue, we found that a fraction of cutaneous $\mathrm{CD} 4^{+} \mathrm{CLA}{ }^{+} \mathrm{T}$ cells exited the tissue in these explant cultures and could be detected in the culture media. This tissue exit was associated with downregulation of CD69 by a fraction of both $\mathrm{CD} 103^{+}$and $\mathrm{CD} 103^{-}$cells (Fig. 1, D and E). Importantly, the input skin contained virtually no $\mathrm{CD} 69^{-} \mathrm{CD} 103^{+} \mathrm{CD} 4^{+} \mathrm{T}$ cells (Fig. 1D), and CD103 expression was not induced on blood-derived $\mathrm{CD}^{+}{ }^{+} \mathrm{T}$ cells cultured in parallel (not shown), indicating that CD69 was indeed downregulated by $\mathrm{CD}_{103^{+}} \mathrm{T}_{\mathrm{RM}}$ in these cultures. Additionally, the $\mathrm{CD} 103^{+}$cells found in the media did not express the chemokine receptor CCR7 (Fig. 1D), and thus these cells are distinct from $\mathrm{CD}^{-} 9^{-} \mathrm{CD} 103^{+/ l o}$ cells that 
undergo CCR7-dependent migration from the skin to the draining lymph nodes in mice (16), and from the $\mathrm{CCR} 7{ }^{+} \mathrm{CD} 62 \mathrm{~L}^{-}$migratory memory $\left(\mathrm{T}_{\mathrm{MM}}\right.$ ) cells described in human skin (2). By contrast, compared to $\mathrm{CD} 4^{+} \mathrm{T}$ cells, fewer $\mathrm{CD} 8^{+} \mathrm{T}$ cells exited the tissue in these skin explant cultures (Fig 1D), consistent with more prolonged tissue-residency of the skin CD8 ${ }^{+}$ $\mathrm{T}_{\mathrm{RM}}$ population in some mouse models (7)(8).

To determine if $\mathrm{CD}^{+} \mathrm{T}_{\mathrm{RM}}$ could exit the skin in vivo, we used a xenografting model in which human skin was transplanted onto immunodeficient NOD, scid, common- $\gamma$ chaindeficient (NSG) mice (17). T cells that had exited the skin were analyzed in the spleen. Similar to our explant studies, $\mathrm{T}$ cells exited the skin in all animals examined, including $\mathrm{CLA}^{+} \mathrm{CD} 103^{+} \mathrm{T}$ cells in 2 of the 3 recipient animals (Fig. 1, F and G). Importantly, expression of CD103 in the periphery is not induced by the xenogeneic system we used, as we did not observe induction of CD103 expression by $\mathrm{CD}^{+}{ }^{+} \mathrm{T}$ cells in NSG mice upon transfer of total PBMC (Fig. S2).

\section{Identification of $\mathrm{CD4}^{+} \mathrm{CLA}^{+} \mathrm{CD} 103^{+} \mathrm{T}$ cells in circulation of healthy humans}

Among the $\mathrm{CD} 4{ }^{+} \mathrm{CLA}^{+} \mathrm{CD} 45 \mathrm{RA}^{-} \mathrm{T}$ cells in human blood, we noted a small population of $\mathrm{CD}_{103}{ }^{+} \mathrm{CD} 9^{-}$cells (Fig. 1D), and reasoned that these may represent $\mathrm{CD} 4^{+} \mathrm{CLA}^{+} \mathrm{CD} 103^{+}$ cells that had exited the skin and re-entered the circulation. To more comprehensively examine circulating $\mathrm{CLA}^{+} \mathrm{CD}_{103^{+}} \mathrm{T}$ cells and determine if they constitute a phenotypically distinct $\mathrm{T}$ cell population, we performed mass cytometry analysis of CLA ${ }^{+} \mathrm{T}$ cells in the blood of 5 healthy subjects using markers associated with cell lineage, functional differentiation and migration of $\mathrm{CD}^{+}{ }^{+} \mathrm{T}$ cells. Cluster analysis following t-distributed Stochastic Neighbor Embedding (t-SNE) revealed 10 clusters of $\mathrm{CD}^{+}{ }^{+} \mathrm{CD} 45 \mathrm{RA}^{-} \mathrm{CLA}^{+}$ memory $\mathrm{T}$ cells present in all subjects examined (Fig. 2A, Fig. S3), including 5 clusters of $\mathrm{CD} 4^{+} \mathrm{T}$ cells (Fig. 2B). Interestingly, most $\mathrm{CD} 4^{+} \mathrm{CD} 103^{+}$cells clustered together as a phenotypically discrete population (cluster 10). In addition to being positive for $\mathrm{CD} 103$ and its dimerization partner $\beta 7$ integrin, cells in this cluster expressed chemokine receptors strongly indicative of skin tropism such as CCR4, CCR6, and CCR10, but were largely negative for CCR7 (Fig. 2, B and C) (18)(19). Additionally, cells in cluster 10 were low for expression of markers of regulatory T cells (Foxp3, CD25), T helper (Th) 1 cells (CXCR3), Th17 cells (CD161) or natural killer T cells (CD56).

Using conventional flow cytometry, we directly compared the abundance and phenotype of circulating and skin-resident $\mathrm{CD} 4^{+} \mathrm{CLA}^{+} \mathrm{CD}_{103}{ }^{+} \mathrm{T}$ cells. In both blood and skin, $\mathrm{CD} 103$ and CCR7 clearly delineated 3 populations of $\mathrm{CLA}^{+} \mathrm{T}$ cells (Fig. 3, A and B), but the distribution of these populations differed dramatically between sites. Whereas CD4 ${ }^{+} \mathrm{CLA}$ ${ }^{+} \mathrm{CD} 103^{+}$memory $\mathrm{T}$ cells were common in the skin $\left(26+/-9 \%\right.$ of $\mathrm{CD} 4{ }^{+} \mathrm{CLA}^{+} \mathrm{T}$ cells), they were a rare population in the blood, representing on average $<2 \%$ of circulating CD $4^{+} \mathrm{CLA}$ ${ }^{+} \mathrm{CD} 45 \mathrm{RA}^{-}$memory $\mathrm{T}$ cells, and $<0.2 \%$ of total $\mathrm{CD} 4^{+} \mathrm{T}$ cells (Fig. 3C, Fig. S4A). Based on previous estimates of the total number of $\mathrm{T}$ cells in human skin and blood (14), we calculate that the number of $\mathrm{CD}^{+} \mathrm{CLA}^{+} \mathrm{CD}_{103}{ }^{+}$cells in the skin is approximately 250 -fold higher than in the blood, highlighting the disequilibrium of this population between the skin and circulation (Fig. S4B). Within the skin, $\mathrm{CD}^{+}{ }^{+} \mathrm{CLA}^{+} \mathrm{CD} 103^{+}$cells were found in both the dermis and epidermis (Fig. S4C). 
$\mathrm{CD}^{+}{ }^{+} \mathrm{CLA}^{+} \mathrm{CD} 103^{+} \mathrm{T}$ cells in the skin shared the $\mathrm{CCR} 4^{+} \mathrm{CCR} 6^{+} \mathrm{CXCR} 3^{-}$chemokine receptor profile with circulating $\mathrm{CD}^{+} \mathrm{CLA}^{+} \mathrm{CD} 103^{+}$memory $\mathrm{T}$ cells. Additionally, $\mathrm{CD} 4{ }^{+} \mathrm{CLA}^{+} \mathrm{CD}_{103}{ }^{+}$cells in the blood and all populations in the skin were largely negative for CD49d (Fig. 3D). Like CD103, CD49d (also known as a4 integrin) can pair with $\beta 7$ integrin, and in this combination promotes $\mathrm{T}$ cell localization to the intestinal mucosa (20). $\mathrm{CD}^{+} \mathrm{CLA}^{+} \mathrm{CD} 103^{+}$cells in the skin and blood were also $\mathrm{CD} 27^{-}$indicating that they are terminally differentiated (21), whereas most circulating $\mathrm{CD}^{+} \mathrm{CLA}^{+} \mathrm{CD} 103^{-}$memory $\mathrm{T}$ cells were $\mathrm{CD} 27^{+}$. Additionally, significant fractions of circulating $\mathrm{CD} 4^{+} \mathrm{CLA}{ }^{+} \mathrm{CD} 103^{+}$memory T cells expressed the markers CD101 and CD9, which were also expressed by the majority of $\mathrm{CD}^{+}{ }^{+} \mathrm{CLA}{ }^{+} \mathrm{CD} 103^{+}$cells in the skin (Fig. 3E). Indeed, CD101 was recently identified as a marker of $\mathrm{CD}^{+}{ }^{+} \mathrm{CD} 103^{+} \mathrm{T}_{\mathrm{RM}}$ populations in various human tissues that was also expressed by $\mathrm{CD}^{+}$lung $\mathrm{T}_{\mathrm{RM}}$ (3)(22), whereas $\mathrm{CD} 9$ is highly expressed by keratinocytes and $\mathrm{T}$ cells in the skin, where it modulates TGF- $\beta$ signaling, integrin function, cell migration, and wound healing (23)(24). However, consistent with downregulation of CD69 by $\mathrm{T}$ cells that migrated out of the skin in our tissue explant cultures, $\mathrm{CD} 4^{+} \mathrm{CLA}^{+} \mathrm{CD} 103^{+}$ cells in the blood were almost all CD69- (Fig. 3E).

\section{$\mathrm{CD4}^{+}{ }^{+} \mathrm{CLA}{ }^{+} \mathrm{CD} 103^{+} \mathrm{T}$ cells from blood and skin share a transcriptional and functional profile}

To assess the transcriptional signature of circulating and skin-resident $\mathrm{CD} 4{ }^{+} \mathrm{CLA}^{+} \mathrm{CD} 103^{+} \mathrm{T}$ cells, we performed RNA-sequencing on sorted $\mathrm{CLA}^{+}$memory $\mathrm{CD}^{+}{ }^{+} \mathrm{T}$ cell populations from blood and skin (see Fig. S5 for sort scheme). Analysis of circulating CD4 $4^{+} \mathrm{CLA}$ ${ }^{+} \mathrm{CD} 103^{+} \mathrm{T}$ cells identified a unique signature of 83 genes that were differentially expressed (false discovery rate (FDR) $<0.05$ and fold-change $>2$ ) compared to both $\mathrm{CD} 4^{+} \mathrm{CLA}$ ${ }^{+} \mathrm{CD} 103^{-} \mathrm{CCR} 7^{-}$and $\mathrm{CD} 4^{+} \mathrm{CLA}^{+} \mathrm{CD} 103^{-} \mathrm{CCR} 7^{+}$memory populations in the blood (Fig. $4 \mathrm{~A})$. This $\mathrm{CD} 103^{+}$gene signature derived from blood was also significantly enriched in CD4 ${ }^{+} \mathrm{CLA}^{+} \mathrm{CD} 103^{+}$vs. $\mathrm{CD}^{+} \mathrm{CLA}^{+} \mathrm{CD} 103^{-} \mathrm{CCR} 7^{-} \mathrm{T}$ cells in the skin (Fig. 4B), consistent with the notion that circulating $\mathrm{CD} 4{ }^{+} \mathrm{CLA}^{+} \mathrm{CD} 103^{+}$cells represent skin $\mathrm{T}$ cells that downregulated CD69 to exit the tissue. Indeed, hierarchical clustering based on this gene signature grouped $\mathrm{CD} 4^{+} \mathrm{CLA}^{+} \mathrm{CD} 103^{+}$cells from skin and blood into a single branch (Fig. $4 C)$.

CD103 expression by cutaneous $\mathrm{T}_{\mathrm{RM}}$ is induced upon their migration into the skin by TGF$\beta$ (25), which is produced and activated by epidermal keratinocytes and dermal fibroblasts (2)(26)(27). Consistent with this, several TGF- $\beta$ related genes were upregulated in both circulating and skin-resident $\mathrm{CD} 4^{+} \mathrm{CLA}^{+} \mathrm{CD} 103^{+}$cells (Fig. 4D and Fig. S6). Moreover, along with ITGAE (the gene encoding CD103), CD27 and CD101, we identified additional $\mathrm{T}_{\mathrm{RM}^{-}}$associated genes that were differentially expressed by circulating $\mathrm{CD} 4^{+} \mathrm{CLA}^{+} \mathrm{CD} 103^{+}$ cells, including CCR8 (28), CXCR6 (3), EOMES (29) and PPARG (30). We also identified overlapping functional modules of genes differentially expressed by $\mathrm{CD} 4^{+} \mathrm{CLA}^{+} \mathrm{CD} 103^{+} \mathrm{T}$ cells that control cellular migration and adhesion, and that modulate host defense and tissue inflammation (Fig. 4D and Fig. S6).

To complement this transcriptomic study, we assessed the function of memory $\mathrm{T}$ cells from skin and blood following ex vivo stimulation and intracellular cytokine staining. Among effector cytokines, production of IL-22 and IL-13 was significantly enriched in CD4 ${ }^{+}$CLA 
${ }^{+} \mathrm{CD} 103^{+}$cells from both tissues, but these cells were largely negative for IFN- $\gamma$, IL-17A or IL-4 (Fig. 5). Although GM-CSF production was also highly enriched in CD4 ${ }^{+} \mathrm{CLA}$ ${ }^{+} \mathrm{CD}_{103}{ }^{+}$cells in the blood, production in the skin was low in all $\mathrm{T}$ cell populations (Fig. 5, $\mathrm{D}$ and $\mathrm{E})$. This cytokine phenotype is consistent with that of Th22 cells (31)(32), and distinguished $\mathrm{CD}^{+} \mathrm{CLA}^{+} \mathrm{CD} 103^{+} \mathrm{T}$ cells from $\mathrm{CD} 4{ }^{+} \mathrm{CLA}^{+} \mathrm{CD} 103^{-}$and $\mathrm{CD} 4{ }^{+} \mathrm{CLA}$ ${ }^{-} \mathrm{CD} 103^{-} \mathrm{T}$ cells in both skin and blood. Co-production of IL-22 and IL-13 (Fig. S7) is indicative of a role for $\mathrm{CD} 4^{+} \mathrm{CLA}^{+} \mathrm{CD} 103^{+} \mathrm{T}$ cells in promoting normal tissue homeostasis and repair in the skin (33)(34). Consistent with this, $\mathrm{CD} 4{ }^{+} \mathrm{CLA}^{+} \mathrm{CD}_{103}{ }^{+}$cells in the blood and skin differentially expressed a set of genes implicated in tissue-repair responses, such as CD9 (24), MUC16(35)(36), and LGALS3 (37), as well as the receptor components for the damage-associated epithelial cell products IL-25 (IL17RA, IL17RB) and prostaglandin E2 (PTGER3) (Fig. 4F, Fig. S6) (38)(33)(39). CD4 ${ }^{+} \mathrm{CLA}^{+} \mathrm{CD} 103^{+} \mathrm{T}$ cells in both the skin and blood expressed IL26, a cytokine that can also have direct anti-microbial activity against Staphylococcus aureus and other extracellular bacteria (40)(41). Thus, the CD4 ${ }^{+}$CLA ${ }^{+} \mathrm{CD} 103^{+} \mathrm{T}$ cell population is functionally well suited to promote both tissue-repair and host-protective responses in the skin.

\section{$\mathrm{CLA}^{+} \mathrm{CD} 103^{+} \mathrm{T}$ cells from human blood and skin are clonally related}

Their shared phenotype, transcriptional signature, and functions suggest that the CD4 ${ }^{+} \mathrm{CLA}$ ${ }^{+} \mathrm{CD} 103^{+} \mathrm{T}$ cells in blood and skin are closely related, and may represent circulating and skin-resident fractions of the same $\mathrm{T}_{\mathrm{RM}}$ population. To directly determine if CD4 ${ }^{+} \mathrm{CLA}$ ${ }^{+} \mathrm{CD} 103^{+} \mathrm{T}$ cells in the skin and blood have a shared clonal origin, we performed TCR $\beta$ sequencing on $\mathrm{CD}^{+} \mathrm{CLA}^{+}$memory $\mathrm{CD} 4^{+} \mathrm{T}$ cells from paired blood and skin samples from four individual donors that were sorted as in Fig. S5. Analysis of unique CDR3 clonotypes showed that sequences from $\mathrm{CD} 4^{+} \mathrm{CLA}^{+} \mathrm{CD} 103^{+} \mathrm{T}$ cells from the skin were found at high frequency in the circulating $\mathrm{CD} 4^{+} \mathrm{CLA}{ }^{+} \mathrm{CD} 103^{+}$cells, and also showed some overlap with $\mathrm{CD} 4^{+} \mathrm{CLA}^{+} \mathrm{CD} 103^{-}$skin $\mathrm{T}$ cells. By contrast, little clonal overlap was observed with circulating $\mathrm{CLA}^{+} \mathrm{CD}^{-} \mathrm{C3}^{-} \mathrm{CCR}^{+}$and $\mathrm{CLA}^{+} \mathrm{CD} 103^{-} \mathrm{CCR} 7^{-} \mathrm{T}$ cells (Fig. 6A and Fig. S8A). Quantitative analysis of TCR repertoire overlap using the Morisita index (42), which accounts for both species presence and abundance, confirmed that the repertoire of skin $\mathrm{CD}^{+}{ }^{+} \mathrm{CLA}^{+} \mathrm{CD} 103^{+} \mathrm{T}$ cells is most similar to that of the circulating $\mathrm{CD} 4^{+} \mathrm{CLA}^{+} \mathrm{CD} 103^{+} \mathrm{T}$ cell population (Fig 6A, right). Reciprocally, circulating $\mathrm{CD}^{+} \mathrm{CLA}^{+} \mathrm{CD} 103^{+}$cells from the blood showed extensive TCR repertoire overlap with skin $\mathrm{CLA}^{+} \mathrm{CD} 103^{+} \mathrm{T}$ cells, but little clonal similarity with the other circulating $\mathrm{CD}^{+} \mathrm{CLA}^{+} \mathrm{T}$ cell populations (Fig 6B, Fig. $\mathrm{S} 8 \mathrm{~A})$. Taken together, these analyses demonstrate the shared clonal origin of the $\mathrm{CD} 4{ }^{+} \mathrm{CLA}$ ${ }^{+} \mathrm{CD} 103^{+} \mathrm{T}$ cell populations in the blood and skin, thereby providing strong evidence that $\mathrm{CLA}^{+} \mathrm{CD} 103^{+} \mathrm{T}$ cells in the blood represent the circulating counterpart of the cutaneous $\mathrm{CLA}^{+} \mathrm{CD} 103^{+} \mathrm{T}_{\mathrm{RM}}$ population. Notably, $\mathrm{CD} 4^{+} \mathrm{CLA}^{+} \mathrm{CD} 103^{+} \mathrm{T}$ cells in both blood and skin showed diverse $\mathrm{V} \beta$ usage (Fig. S8B), and there was virtually no overlap in the TCR $\beta$ sequences in any of the populations examined between the 4 different donors (not shown). Thus, $\mathrm{CD} 4{ }^{+} \mathrm{CLA}^{+} \mathrm{CD}_{103}{ }^{+} \mathrm{T}$ cells in the blood and skin do not appear to be a clonally restricted or invariant $\mathrm{T}$ cell population such as NK $\mathrm{T}$ cells or mucosa-associated invariant $\mathrm{T}$ (MAIT) cells (43). 


\section{$\mathrm{CD4}^{+} \mathrm{CLA}{ }^{+} \mathrm{CD} 103^{+} \mathrm{T}$ cells recirculate from tissues via the lymphatics}

To further determine if $\mathrm{CD}^{+}{ }^{+} \mathrm{CLA}^{+} \mathrm{CD} 103^{+}$cells recirculate from the tissue under physiological conditions, we analyzed human thoracic duct lymph (TDL) collected from chylothorax patients. As in the blood and skin, we identified a CD4 ${ }^{+} \mathrm{CLA}{ }^{+} \mathrm{CD} 103^{+}$ population that lacked the expression of CCR7 (Fig 7A-C). Moreover, a majority of these cells expressed CCR4 and CCR6, but were low for CD27 and negative for CD69 expression (Fig. 7D). CCR7 is required for trafficking to the lymph node via the blood, and it is therefore unlikely that these $\mathrm{CCR}^{-} \mathrm{T}$ cells are recirculating by exiting the blood to the lymph node and then returning to the circulation via the TDL (44). Rather, this further supports the idea that circulating $\mathrm{CD} 4{ }^{+} \mathrm{CLA}^{+} \mathrm{CD} 103^{+} \mathrm{T}$ cells in blood and TDL have exited directly from the skin.

\section{Circulating $\mathrm{CD}^{+}{ }^{+} \mathrm{CLA}+\mathrm{CD} 103^{+} \mathrm{T}_{\mathrm{RM}}$ can reseed distant skin sites}

Exit of cutaneous $\mathrm{CD} 4^{+} \mathrm{CLA}{ }^{+} \mathrm{CD} 103^{+} \mathrm{T}$ cells and their re-circulation may allow them to migrate to distant tissue sites, thereby promoting the efficient distribution of functionally specialized T cells throughout the skin. To directly test this hypothesis in vivo, we employed a skin-xenografting mouse model designed to track tissue exit of human cutaneous T cells, and their subsequent migration to secondary human skin sites. In this system, cultured human keratinocytes and fibroblasts are placed in a grafting chamber that is surgically implanted on NSG mice. The cells undergo spontaneous cell sorting to form epidermal and dermal layers, generating engineered skin (ES) tissue with histological features of human skin as well as the organotypic expression of structural proteins such as human type VII collagen at the epidermal-dermal junction (Fig. 8A) (45). Thus, the ES closely resembles human skin but lacks resident immune cells, and therefore T cell migration into the ES can be definitively monitored.

After healing of the ES (>110 days), mice received skin grafts from healthy donors, and tissues were analyzed three to five weeks later (Fig. 8, B and C). Similar to Figs 1F and 1G, $\mathrm{CD}^{+}{ }^{+} \mathrm{CLA}^{+} \mathrm{CD} 103^{+} \mathrm{T}$ cells had exited the skin grafts and were found in the spleens of all recipient animals. Additionally, in 5 of 7 recipient mice, $\mathrm{CD} 4^{+} \mathrm{CLA}{ }^{+} \mathrm{CD} 103^{+} \mathrm{T}$ cells were also found in the ES (Fig. 8, D and E), whereas no human cells were found in adjacent murine skin (Fig. S9). Similar to what we observed in human blood and skin, CD9 and CD69 were downmodulated on $\mathrm{CD}^{+} \mathrm{CLA}^{+} \mathrm{CD} 103^{+} \mathrm{T}$ cells found in the spleen, but were reexpressed by cells entering the ES and CD27 expression remained low in all tissue sites (Fig. 8F). Finally, we used the ES system to interrogate the in vivo migration behavior of circulating $\mathrm{CD}_{4}{ }^{+} \mathrm{CLA}{ }^{+} \mathrm{CD} 103^{+} \mathrm{T}$ cells from the blood. Upon transfer of PBMC into NSG mice carrying ES grafts (Fig. 8G), we found that $\mathrm{T}$ cells migrated to the ES, and that $\mathrm{CD}^{+}{ }^{+} \mathrm{CLA}^{+} \mathrm{CD}_{103}{ }^{+}$cells were significantly enriched in the ES versus the spleen (Fig. 8, H and I). Together, these data demonstrate that $\mathrm{CD} 4^{+} \mathrm{CLA}^{+} \mathrm{CD} 103^{+} \mathrm{T}$ cells that exit from the skin upon grafting or that are found in the blood of healthy individuals have the ability to migrate to and populate secondary skin sites. 


\section{Discussion}

$\mathrm{T}_{\mathrm{RM}}$ populations mediate optimal protective responses to site-specific challenges in nonlymphoid tissues, and are most readily identified by their expression of CD69 and/or CD103 (4)(2). Using tissue explant cultures and a skin-xenografting mouse model, we made the surprising discovery that $\mathrm{CD} 4{ }^{+} \mathrm{CLA}^{+} \mathrm{CD} 69^{+} \mathrm{CD} 103^{+} \mathrm{T}$ cells in human skin can downregulate CD69 and exit the tissue. This is consistent with recent observations in murine systems showing that secondary stimulation mobilized $\mathrm{CD} 8^{+} \mathrm{T}$ cells from non-lymphoid tissues (including the skin) that subsequently established residence within draining secondary lymphoid organs (SLO) (46). However, this study did not establish from which skin-resident population these cells were derived, or whether these mobilized cells could further recirculate to other peripheral non-lymphoid tissue sites. We also identified $\mathrm{CD} 4^{+} \mathrm{CLA}^{+} \mathrm{CD}_{103^{+}} \mathrm{T}$ cells as a distinct population of circulating $\mathrm{T}$ cells that are clonally related to the $\mathrm{CD} 4{ }^{+} \mathrm{CLA}^{+} \mathrm{CD} 103^{+} \mathrm{T}_{\mathrm{RM}}$ population in the skin. Importantly, the phenotypic, functional and transcriptional profile of circulating $\mathrm{CD} 4^{+} \mathrm{CLA}^{+} \mathrm{CD} 103^{+} \mathrm{T}$ cells is consistent with their origin and function within the skin, a TGF- $\beta$-rich barrier site exposed to microbial threats and frequent tissue damage. Finally, we show that upon exiting the skin, CLA ${ }^{+}$CLA ${ }^{+} \mathrm{CD} 103^{+} \mathrm{T}$ cells can migrate via the circulation to secondary skin sites where they reacquire markers of tissue residency such as CD69. Based on these features, we propose that blood and skin $\mathrm{CD}^{+} \mathrm{CLA}^{+} \mathrm{CD} 103^{+} \mathrm{T}$ cells represent components of the same $\mathrm{T}_{\mathrm{RM}}$ population that undergoes basal recirculation, but is maintained in substantial disequilibrium between these tissues.

Our data challenge current concepts regarding the strict tissue compartmentalization of $\mathrm{T}$ cell memory in humans, and instead support a model in which cells of the CD4 ${ }^{+}$CLA ${ }^{+} \mathrm{CD} 103^{+} \mathrm{T}_{\mathrm{RM}}$ population can transiently forgo their cutaneous location before re-assuming residency at distant skin sites. Whether tissue-exit of cutaneous $\mathrm{CD}^{+}{ }^{+} \mathrm{CLA}^{+} \mathrm{CD} 103^{+} \mathrm{T}$ cells is a stochastic process or actively triggered mobilization remains to be determined. In the context of our studies in explant cultures and in skin-humanized mice, tissue damage unavoidably associated with surgical skin acquisition is one potential trigger that may have impacted $\mathrm{T}_{\mathrm{RM}}$ mobilization. However, we detected $\mathrm{CD} 4^{+} \mathrm{CLA}^{+} \mathrm{CD}_{103}{ }^{+}$cells in the blood and lymph of all donors analyzed, which indicates that a small fraction of the CD4 $4^{+}$CLA ${ }^{+} \mathrm{CD} 103^{+} \mathrm{T}_{\mathrm{RM}}$ population recirculates even in the absence of clinical skin infection, inflammation or tissue damage.

Our xenografting studies allowed us to further follow the fate of tissue-derived $\mathrm{T}$ cells, and we found that $\mathrm{CD}^{+}{ }^{+} \mathrm{CLA}^{+} \mathrm{CD} 103^{+} \mathrm{T}$ cells from either skin grafts or from human blood can migrate to and preferentially seed secondary human skin sites. This tissue-seeding occurred in the absence of tissue damage or local inflammation since the recipient ES tissue was fully healed ( $>110$ days) and thus lacked expression of damage-associated molecules such as IL-1 $a$, IL-1 $\beta$, IL-18 and TNF- $\alpha$ that might increase recruitment of circulating cells (47). However, it remains possible that recruitment to secondary skin sites is increased by damage-associated stress. This might offer an intriguing explanation to the hitherto unexplained Koebner phenomenon, in which lesions in $\mathrm{T}_{\mathrm{RM}^{-}}$-mediated diseases such as psoriasis and mycosis fungoides can spread to otherwise healthy (non-infected) skin sites upon triggers such as mechanical trauma, burns, friction or UV-irradiation (48)(49)(50). 
Human skin-resident $\alpha \beta \mathrm{T}$ cells can promote tissue-repair in skin organ culture models (51). Although the precise role of the $\mathrm{CD} 4{ }^{+} \mathrm{CLA}^{+} \mathrm{CD}_{103}{ }^{+}$population in skin immunity and homeostasis remains to be established in vivo, their transcriptional and functional profile is indicative of a function in wound-healing and tissue-repair responses. The signature cytokines produced by $\mathrm{CD} 4^{+} \mathrm{CLA}^{+} \mathrm{CD} 103^{+} \mathrm{T}$ cells, IL-22 and IL-13, both have important tissue-repair functions in the skin. IL-22 acts directly on keratinocytes to promote their survival, proliferation, migration and anti-microbial functions (34), whereas IL-13 activates cutaneous fibroblasts and promotes M2 macrophage differentiation and wound healing (52). IL-22 can also induce production of anti-microbial peptides by keratinocytes (53). Thus, the $\mathrm{CD}^{+} \mathrm{CLA}^{+} \mathrm{CD} 103^{+}$population has many of the hallmarks of other lymphocyte populations implicated in anti-microbial and tissue-repair responses, such as cutaneous IL-22 producing $\gamma \delta \mathrm{T}$ cells, and IL-13- or IL-22-producing ILC cells (54)(55)(34). In these contexts, it is important to note that we and others found $\mathrm{CD}^{+}{ }^{+} \mathrm{CLA}^{+} \mathrm{CD} 103^{+} \mathrm{T}$ cells in the epidermis and the dermis of the skin (2), and thus they are ideally positioned to modulate the responses of keratinocytes, fibroblasts and skin macrophages and promote both tissue-repair and hostprotective responses.

Mobilization of cutaneous $\mathrm{CD} 4^{+} \mathrm{CLA}{ }^{+} \mathrm{CD} 103^{+} \mathrm{T}$ cells to the circulation would support the distribution of immunity in a large barrier organ such as the skin, as well as provide a reservoir of specialized circulating $\mathrm{T}$ cells that could be rapidly recruited to infected or damaged skin to promote host-defense and tissue-repair. Importantly, our identification of $\mathrm{CD}^{+}{ }^{+} \mathrm{CLA}^{+} \mathrm{CD} 103^{+} \mathrm{T}$ cells as a unique population of circulating $\mathrm{T}$ cells in healthy subjects greatly facilitates the isolation and study of cutaneous $T_{R M}$ from a broadly available human tissue, the blood. This observation may yield new insights into the biology and function of the human skin $\mathrm{T}_{\mathrm{RM}}$ population, and also provides an opportunity for therapeutic manipulation of skin $\mathrm{T}_{\mathrm{RM}}$ in the contexts of cutaneous autoimmunity, infection, and tissuerepair.

\section{Material and Methods}

\section{Study design.}

The objective of this research was to characterize the phenotype, function and migratory behavior of $\mathrm{CD}^{+} \mathrm{T}$ cell populations that express the cutaneous lymphocyte antigen (CLA), and to define the relationship between $\mathrm{CLA}^{+} \mathrm{T}$ cells in the blood and CLA ${ }^{+} \mathrm{T}_{\mathrm{RM}}$ cells in the skin. This was accomplished using blood and skin samples from healthy donors by flow cytometric analysis of cellular phenotype and function, transcriptomic analysis by RNAsequencing, T cell receptor clonotype analysis by TCR-sequencing, and experimental studies of cellular behavior in explant culture models and skin xenograft studies using immunodeficient mice. Blood samples from healthy donors were obtained by standard phlebotomy. Normal human skin was obtained from patients undergoing elective surgery (panniculectomy, elective breast reduction), in which skin was discarded as a routine procedure. In one case, skin and blood was obtained from a treatment naïve subject undergoing surgery for mammary carcinoma, and data from this subject is specifically marked in the figures. Samples of subjects of both sexes were included in the study. Ages ranged from $17-70$. All samples were obtained upon written informed consent at the 
University Hospital Salzburg, Austria, the University of Pennsylvania and the Children's Hospital of Philadelphia (Philadelphia, PA), or the Virginia Mason Medical Center in Seattle, WA, USA. All studies were approved by the Salzburg state Ethics Commission (decision: according to Salzburg state hospital law no approval required) (Salzburg, Austria), or the Institutional Review Board of the University of Pennsylvania and the Children's Hospital of Philadelphia (Philadelphia, PA), or the Institutional Review Board of the

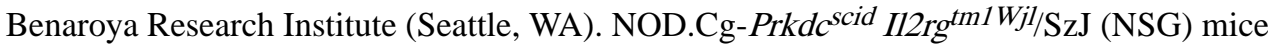
were obtained from The Jackson Laboratory and bred and maintained in a specific pathogenfree facility in accordance with the guidelines of the Central Animal Facility of the University of Salzburg. All animal studies were approved by the Austrian Federal Ministry of Science, Research and Economy. No statistical method was used to predetermine sample size. Sample sizes were selected based on the availability of human blood and skin specimens and were large enough to ensure achieve a greater than $80 \%$ probability of identifying an effect of $>20 \%$ in measured variables. Two to three independent experiments (biological replicates) were conducted to validate each finding.

\section{Skin explant cultures.}

Skin was washed in PBS with $1 \%$ Pen/Strep and $0.1 \%$ Primocin (Invivogen; ant-pm-1) for 5 minutes. Small skin pieces of $1-2 \mathrm{~mm}$ were generated using forceps and sharp scissors. Pieces were placed in $60 \mathrm{~mm}$ dish and allowed to adhere for 10 minutes. Crawl-out medium consisting of 50\% Epilife (Gibco; MEPICF500) and 50\% RPMI-complete (RPMIc: RPMI 1640 (Gibco; 31870074) with 5\% human serum (Sigma-Aldrich; H5667 or H4522), 1\% penicillin/streptomycin (Sigma-Aldrich; P0781), 1\% L-glutamine (Gibco; A2916801), 1\% NEAA (Gibco; 11140035), 1\% sodium pyruvate (Sigma-Aldrich; S8636) and 0.1\% $\beta$ mercaptoethanol (Gibco; 31350-010)) was added to explant cultures. Seven days later, cells in culture medium were analyzed by flow cytometry.

\section{Cytometry by time-of-flight (СyTOF).}

Human frozen PBMCs were thawed and rested for $12-15 \mathrm{~h}$. The samples were washed with Ca- and Mg-free PBS (Sigma; D8537) and stained with 50 $\mu$ M Cisplatin (Enzo Life Sciences; ALX-400-040-M250) in PBS for 1 minute to exclude dead cells. The cells were washed and resuspended with Human TruStain FcX (Biolegend; 422302) for five minutes before adding the primary surface staining cocktail for $20 \mathrm{~m}$, washing and staining with the secondary surface cocktail for $20 \mathrm{~m}$. Intracellular staining was performed following fixation and permeabilization using the Maxpar Nuclear Antigen Staining Buffer Set (Fluidigm; 201063) for 60 minutes, after which cells were incubated overnight at $4^{\circ} \mathrm{C}$ with Maxpar Fix and Perm Solution containing 125nM Cell-ID Intercalator-Ir (Fluidigm; 201192A) for DNA staining. Cells were washed with MilliQ $\mathrm{H}_{2} \mathrm{O}$ and resuspended in MilliQ $\mathrm{H}_{2} \mathrm{O}$ spiked with 1/20th Maxpar EQ Four Element Calibration Beads (Fluidigm; 201078) to a density of $<5 \times 10^{5}$ cells $/ \mathrm{mL}$. Data was acquired on a CyTOF 1.5 (Fluidigm) instrument. For analysis, FCS files on gated $\mathrm{CD}^{+}{ }^{+} \mathrm{CLA}^{+}$cells were generated using FlowJo software (Tree Star, Inc.). t-distributed Stochastic Neighbor Embedding (t-SNE) analysis was performed in R using the cytofkit R package, and clustering was performed with FlowSOM. 


\section{T cell isolation from human skin for flow cytometry and RNA-seq.}

For isolation of cells from full-thickness skin, tissue was minced and digested using collagenase Type 4 and DNase as previously described (56). Briefly, subcutaneous fat was removed before skin was minced with dissection scissors and surgical scalpel. Approximately $1 \mathrm{~cm}^{2}$ of skin was digested overnight in $5 \% \mathrm{CO}_{2}$ at $37^{\circ} \mathrm{C}$ with $3 \mathrm{ml}$ of digestion mix containing $0.8 \mathrm{mg} / \mathrm{ml}$ collagenase Type 4 (Worthington; \#LS004186) and $0.02 \mathrm{mg} / \mathrm{ml}$ DNase (Sigma-Aldrich; DN25) in RPMIc. Samples were filtered, washed with RPMI and PBS and stained for flow cytometry/cell sorting or stimulated for intracellular cytokine staining. For separation of human epidermis and dermis, skin was washed in PBS with $1 \%$ Pen/Strep and $0.1 \%$ Primocin for 5 minutes prior to removal of fat tissue. Skin pieces of 2-3 mm in diameter were incubated overnight with $0.25 \%$ Dispase II (SigmaAldrich; D4693) in RPMIc and dermis and epidermis separated with forceps. The separated tissue layers were then further minced and digested with collagenase Type 4 and DNase to generate single cell suspensions for flow cytometric analysis.

\section{PBMC isolation for flow cytometry and RNA-seq.}

Human PBMCs were isolated using Ficoll-Hypaque (GE-Healthcare; GE17-1440-02) gradient separation. For RNA-seq CD4 ${ }^{+} \mathrm{T}$ cells were enriched using CD4 microbeads (Miltenyi; 130-045-101) and $4 \times 10^{6}$ cells/ml were resuspended in RPMIc with $50 \mathrm{U} / \mathrm{ml}$ IL-2 (Immunotools; 11340023) in 24-well plate wells and stimulated for $20 \mathrm{~h}$ with $25 \mu \mathrm{l} / \mathrm{ml}$ ImmunoCult CD3/CD28 T cell activator (Stemcell; 10971) prior to staining and cell sorting.

\section{Flow cytometry.}

Cryopreserved PBMC or TDL cells were rested overnight at $37^{\circ} \mathrm{C}$ and $5 \% \mathrm{CO}_{2}$ in complete medium (RPMI supplemented with 10\% FBS, 2 mM L-glutamine, $100 \mathrm{U} / \mathrm{ml}$ penicillin, and $100 \mathrm{mg} / \mathrm{ml}$ streptomycin), washed and stained for flow cytometry. For sorting, cells were stained in FACS buffer (PBS + 1\% FBS +1 mM EDTA) for surface markers. For detection of intracellular cytokine production, skin single cell suspensions and PBMCs were stimulated with $50 \mathrm{ng} / \mathrm{ml}$ PMA (Sigma-Aldrich; P8139) and $1 \mu \mathrm{g} / \mathrm{ml}$ ionomycin (SigmaAldrich; I06434) with $10 \mu \mathrm{g} / \mathrm{ml}$ brefeldin A (Sigma-Aldrich; B6542) for $3.5 \mathrm{hrs}$. For permeabilization and fixation Cytofix/Cytoperm kit was used (BectonDickinson; RUO 554714). Data were acquired on LSR Fortessa, LSRII, FACSymphony (all BD Biosciences) or Cytoflex LS (Beckman Coulter) flow cytometers and analyzed using FlowJo software (FlowJo LLC).

\section{Antibodies and reagents.}

A detailed list of the antibodies and reagents used can be found in Table S1.

\section{Analysis of thoracic duct lymph (TDL) samples.}

Thoracic duct lymph was collected and processed from patients with chylopericardium and chylothorax as previously published (57)(58). Cells were washed in PBS and stained for CXCR3, CCR4, CCR6, and CCR7 at $37^{\circ} \mathrm{C}, 5 \% \mathrm{CO}_{2}$ for 20 minutes. All subsequent incubations were performed in the dark at room temperature. Cells were stained for viability exclusion for 10 minutes. Antibody cocktail mix was added and incubated for 20 minutes. 
Cells were fixed with PBS with $1 \%$ paraformaldehyde and stored in the dark at $4{ }^{\circ} \mathrm{C}$ overnight until acquisition. Data were collected on a BD FACSymphony flow cytometer (BD Biosciences) and analyzed using FlowJo software (FlowJo LLC).

\section{RNA sequencing.}

500 cells per population were sorted into lysis buffer using a BD FACSARIA III or FACSFUSION instruments (BD Biosciences), and cDNA was prepared using the SMARTSeq v4 Ultra Low Input RNA Kit for Sequencing (Takara). Library construction was performed using the NexteraXT DNA sample preparation kit (Illumina) using half the recommended volumes and reagents. Dual-index, single-read sequencing of pooled libraries was run on a HiSeq2500 sequencer (Illumina) with 58-base reads and a target depth of 5 million reads per sample. Base-calling and demultiplexing were performed automatically on BaseSpace (Illumina) to generate FASTQ files.

\section{RNA-seq analysis.}

The FASTQ files were processed in order to remove reads of zero length (fastq_trimmer v.1.0.0), remove adapter sequences (fastqmef tool v.1.1.2) and perform quality trimming from both ends until a minimum base quality $\geq 30$ (FASTQ quality trimmer tool v.1.0.0). Reads were aligned to the human reference genome (build hg38) with TopHat (v.1.4.0) and read counts per Ensembl gene ID were quantified with htseq-count (v.0.4.1). Quality metrics for the FASTQ and BAM/SAM files were generated with FastQC (v.0.11.3) and Picard (v.1.128). Processing of FASTQ and BAM/SAM files was executed on the Galaxy workflow platform of Globus Genomics. Statistical analysis of gene expression was assessed in the $\mathrm{R}$ environment (v.3.4.4). Samples with a total number of fastq reads below $10^{6}$, mapped reads below $70 \%$ or median $\mathrm{CV}$ of coverage > 1 were excluded from further analysis. Mapping Ensembl Gene IDs to HGNC gene symbols was achieved through biomaRt (GRCh38.p10). Genes were filtered for protein coding genes and those with an expression of CPM > 2 in at least $10 \%$ of the libraries. A linear model for gene expression was fit to the filtered 12,293 genes using limma (v3.34.9)(59), considering donor effects through a random factor. For visualizations the random effect of the model was approximated by removing the donor effect from the expression data with limma::removeBatchEffect. Genes found to be significantly different (adj.p.val $<0.05$ and fold-change $>2$ ) between $\mathrm{CD}_{103}{ }^{+}$cells and CD $103^{-}{ }^{-} \mathrm{CR} 7^{+}$cells as well as between $\mathrm{CD} 103^{+}$cells and $\mathrm{CD} 103^{-} \mathrm{CCR} 7^{-}$cells in the blood were defined as the $\mathrm{CD} 103^{+}$gene signature. Enrichment of the $\mathrm{CD}_{103^{+}}$gene signature in the ranked list of $\mathrm{CD} 103^{+}$cells vs $\mathrm{CD} 103^{-} \mathrm{CCR} 7^{-}$cells in the skin was visualized with limma::barcodeplot and significance determined by rotation gene set testing with limma::roast.

\section{TCR $\beta$ sequencing and analysis.}

A minimum of 2,000 cells T cells from the indicated populations were sorted into RPMIc, and genomic DNA was prepared using the QIAamp DNA Micro Kit (Qiagen). Amplification and sequencing was performed using the immunoSEQ® Assay (Adaptive Biotechnologies, Seattle, WA), which combines multiplex PCR with high throughput sequencing and a bioinformatics pipeline for TCR $\beta$ CDR3 analysis (60). Data analysis was performed using Adaptive Biotechnologies ImmunoSeq Analyzer 3.0 software and R version 3.5.1. Data for 
the analysis in $\mathrm{R}$ was exported through the export function in the Rearrangement details view. Circle plots for individual donors were created by downsampling populations with more than 1000 unique rearrangements (weighted based on relative abundance of each individual clonotype) and matching TCR chains with the R package TCRtools (https:// github.com/mjdufort/TCRtools). Links between the blood or skin $\mathrm{CD} 103^{+}$reference population and all other populations are displayed in the circle plot. For V gene usage, we removed unknown and ambiguous mappings and computed the percentage of clones using each $\mathrm{V}$ gene among each sample. The plot includes $\mathrm{V}$ genes that have a usage $25 \%$ in at least one sample.

\section{Generation of engineered skin (ES).}

Human keratinocytes and fibroblasts were isolated from normal human skin and immortalized using human papilloma virus type oncogenes E6/E7 as previously described (61). These were cultured in Epilife (Gibco, MEPICF500) and DMEM (Gibco; 11960-044) containing 2\% L-Glutamine, 1\% Pen/Strep, 10\% FBS, respectively. For transplantation, 80\% confluent cells were trypsinized (TrypLE express, Gibco; 12604021) washed with PBS and counted. ES tissue was generated in vivo in mice by placing $1-2 \times 10^{6}$ keratinocytes mixed

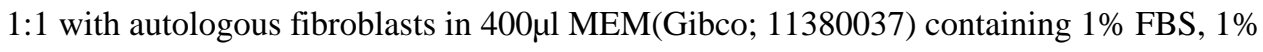
L-Glutamine and 1\% NEAA in grafting chambers as previously described (45).

\section{Transplantation of human skin or PBMC transfer.}

$8 \mathrm{~mm}$ punch biopsies of human skin were trimmed to an average thickness of $0.5-1 \mathrm{~mm}$. Transplants were soaked in PBS $+1 \%$ Pen/Strep $+0.1 \%$ Primocin (Invitrogen; ant-pm-1) for 5 minutes and kept on ice in a sterile container with PBS soaked gauze until transplantation. NSG mice were anesthetized and full thickness wound bed prepared using surgical scissors. Three grafts/mouse were placed on the back and fixed using surgical skin glue (Histoacryl; BRAUN). Transplants were covered with paraffin gauze dressing and bandaged with selfadhesive wound dressing. Bandages were removed after 7 days. In other experiments PBMC were thawed and rested in media overnight before transfer into NSG recipient mice $\left(2.5 \times 10^{6}\right.$ cells/animal). After transfer of human cells (PBMC or skin grafting) mouse neutrophils were depleted with anti-Gr-1 antibody (InVivoMab clone RB6-8C5; $100 \mu \mathrm{g}$ /animal i.p. every 5-7 days) (62)(63).

\section{Histological staining of skin sections.}

Normal human skin, ES grafts and adjacent murine skin was excised and frozen in TissueTek O.C.T. Compound (Sakura; TTEK). $7 \mu \mathrm{m}$ cryosections were stained with Hemalum solution acid (Carl Rorth; T865.1) and Eosin Y aqueous solution (Sigma, 201192A). Human type VII collagen was stained by immunofluorescence using anti-human type VII collagen antibody (anti-NC-1 domain of type VII collagen (LH7.2) kindly provided by Dr. Alexander Nyström, University of Freiburg, Germany) and goat anti-rabbit IgG Alexa Fluor 488 (ThermoFisher; A11008) secondary antibody, and nuclear DAPI staining (ProLong ${ }^{\text {TM }}$ Gold Antifade Mountant with DAPI, Invitrogen; P36931). 


\section{Tissue preparation from mice.}

Mice were euthanized using $\mathrm{CO}_{2}$ asphyxiation followed by cervical dislocation. Single cell suspensions were generated from spleen, ES and human skin grafts and leukocytes analyzed by flow cytometry. For T cell isolation from murine skin for flow cytometry, approx. $3 \mathrm{~cm}^{2}$ of shaved dorsal mouse skin were harvested and single cell suspensions prepared as in (64) and stained for flow cytometry.

\section{Statistical analysis.}

Statistical significance of data was calculated with Prism 6.0 software (GraphPad) by oneway ANOVA with Tukey's or Dunnett's multiple comparisons test, or by paired t-test as indicated. Error bars indicate mean \pm standard deviation.

\section{Supplementary Material}

Refer to Web version on PubMed Central for supplementary material.

\section{Acknowledgements}

We thank Dr. A. Sir and Dr. R. Reitsamer of the Breast Center of the University Hospital Salzburg, Paracelsus Medical University Salzburg, Austria for providing us with skin and blood samples. We also thank Anna Hochreiter, MSc, and Anna Raninger, MSc, from the Flow Cytometry Core facility at the Cell Therapy Institute, PMU Salzburg. We thank Dr. Stefan Hainzl, EB House Austria, Department of Dermatology, University Hospital of the Paracelsus Medical University Salzburg, Austria, for the immortalization of primary human keratinocytes and fibroblasts. We further thank Ariane Benedetti for technical assistance and for performing the skin histology. In Seattle, we thank Kassidy Benoscek and Florence Roan for help in obtaining skin and blood samples, Thien SonNguyen for frozen PBMC, Alice Weidemann for help with CyTOF, Vivian Gersuk for help with RNA-seq, and Scott Presnell, Matt Dufort and Hannah DeBerg for helpful discussions on RNA-seq analysis. We also thank Drs. Maxin Itkin (University of Pennsylvania) and Yoav Dori (Children's Hospital of Philadelphia) for obtaining thoracic duct lymph samples.

Funding: This work was supported by the Focus Program "ACBN" of the University of Salzburg, Austria, a grant from the Dystrophic Epidermolysis Bullosa Research Association (DEBRA) International and DEBRA Austria to IKG, NIH grant R01AI127726 awarded to IKG and DJC, and NIH grants R01AI076066 and R01AI118694 awarded to MRB. MMK was part of the PhD program Immunity in Cancer and Allergy, funded by the Austrian Science Fund (FWF, grant W 1213) and received a DOC Fellowship from the Austrian Academy of Sciences.

\section{References}

1. Mueller SN, Mackay LK, Tissue-resident memory T cells: local specialists in immune defence, Nat. Rev. Immunol 16, 79-89 (2016). [PubMed: 26688350]

2. Watanabe R, Gehad A, Yang C, Campbell L, Teague JE, Schlapbach C, Elco C, Huang V, Matos TR, Kupper TS, Clark RA, Human skin is protected by four functionally and phenotypically discrete populations of resident and recirculating memory T cells, Sci Transl Med 7, 279ra39 (2015).

3. Kumar BV, Ma W, Miron M, Granot T, Guyer RS, Carpenter DJ, Senda T, Sun X, Ho S-H, Lerner H, Friedman AL, Shen Y, Farber DL, Human tissue-resident memory T cells are defined by core transcriptional and functional signatures in lymphoid and mucosal sites, Cell Rep 20, 2921-2934 (2017). [PubMed: 28930685]

4. Steinert EM, Schenkel JM, Fraser KA, Beura LK, Manlove LS, Igyártó BZ, Southern PJ, Masopust D, Quantifying Memory CD8 T Cells Reveals Regionalization of Immunosurveillance, Cell 161, 737-749 (2015). [PubMed: 25957682]

5. Klonowski KD, Williams KJ, Marzo AL, Blair DA, Lingenheld EG, Lefrançois L, Dynamics of blood-borne CD8 memory T cell migration in vivo, Immunity 20, 551-562 (2004). [PubMed: 15142524] 
6. Gebhardt T, Wakim LM, Eidsmo L, Reading PC, Heath WR, Carbone FR, Memory T cells in nonlymphoid tissue that provide enhanced local immunity during infection with herpes simplex virus, Nat. Immunol 10, 524-530 (2009). [PubMed: 19305395]

7. Gebhardt T, Whitney PG, Zaid A, Mackay LK, Brooks AG, Heath WR, Carbone FR, Mueller SN, Different patterns of peripheral migration by memory CD4+ and CD8+ T cells, Nature 477, 216219 (2011). [PubMed: 21841802]

8. Collins N, Jiang X, Zaid A, Macleod BL, Li J, Park CO, Haque A, Bedoui S, Heath WR, Mueller SN, Kupper TS, Gebhardt T, Carbone FR, Skin CD4+ memory T cells exhibit combined clustermediated retention and equilibration with the circulation, Nature Communications 7, 11514 (2016).

9. Beura LK, Hamilton SE, Bi K, Schenkel JM, Odumade OA, Casey KA, Thompson EA, Fraser KA, Rosato PC, Filali-Mouhim A, Sekaly RP, Jenkins MK, Vezys V, Haining WN, Jameson SC, Masopust D, Normalizing the environment recapitulates adult human immune traits in laboratory mice, Nature 532, 512-516 (2016). [PubMed: 27096360]

10. Glennie ND, Yeramilli VA, Beiting DP, Volk SW, Weaver CT, Scott P, Skin-resident memory CD4+ T cells enhance protection against Leishmania major infection, J. Exp. Med 212, 14051414 (2015). [PubMed: 26216123]

11. Park CO, Fu X, Jiang X, Pan Y, Teague JE, Collins N, Tian T, O’Malley JT, Emerson RO, Kim JH, Jung Y, Watanabe R, Fuhlbrigge RC, Carbone FR, Gebhardt T, Clark RA, Lin CP, Kupper TS, Staged development of long-lived T-cell receptor $\alpha \beta$ TH17 resident memory T-cell population to Candida albicans after skin infection, J. Allergy Clin. Immunol 142, 647-662 (2018). [PubMed: 29128674]

12. Davies B, Prier JE, Jones CM, Gebhardt T, Carbone FR, Mackay LK, Cutting Edge: TissueResident Memory T Cells Generated by Multiple Immunizations or Localized Deposition Provide Enhanced Immunity, J. Immunol 198, 2233-2237 (2017). [PubMed: 28159905]

13. Clark RA, Resident memory T cells in human health and disease, Sci Transl Med 7, 269rv1 (2015).

14. Clark RA, Chong B, Mirchandani N, Brinster NK, Yamanaka K-I, Dowgiert RK, Kupper TS, The vast majority of CLA+ T cells are resident in normal skin, J. Immunol 176, 4431-4439 (2006). [PubMed: 16547281]

15. Fuhlbrigge RC, Kieffer JD, Armerding D, Kupper TS, Cutaneous lymphocyte antigen is a specialized form of PSGL-1 expressed on skin-homing T cells, Nature 389, 978-981 (1997). [PubMed: 9353122]

16. Bromley SK, Yan S, Tomura M, Kanagawa O, Luster AD, Recirculating memory T cells are a unique subset of CD4+ T cells with a distinct phenotype and migratory pattern, J. Immunol 190, 970-976 (2013). [PubMed: 23255361]

17. King M, Pearson T, Shultz LD, Leif J, Bottino R, Trucco M, Atkinson MA, Wasserfall C, Herold KC, Woodland RT, Schmidt MR, Woda BA, Thompson MJ, Rossini AA, Greiner DL, A new HuPBL model for the study of human islet alloreactivity based on NOD-scid mice bearing a targeted mutation in the IL-2 receptor gamma chain gene, Clin. Immunol 126, 303-314 (2008). [PubMed: 18096436]

18. Klicznik MM, Szenes-Nagy AB, Campbell DJ, Gratz IK, Taking the lead - how keratinocytes orchestrate skin T cell immunity, Immunol. Lett 200, 43-51 (2018). [PubMed: 29969603]

19. Kupper TS, Fuhlbrigge RC, Immune surveillance in the skin: mechanisms and clinical consequences, Nat. Rev. Immunol 4, 211-222 (2004). [PubMed: 15039758]

20. Berlin C, Berg EL, Briskin MJ, Andrew DP, Kilshaw PJ, Holzmann B, Weissman IL, Hamann A, Butcher EC, Alpha 4 beta 7 integrin mediates lymphocyte binding to the mucosal vascular addressin MAdCAM-1, Cell 74, 185-195 (1993). [PubMed: 7687523]

21. Fritsch RD, Shen X, Sims GP, Hathcock KS, Hodes RJ, Lipsky PE, Stepwise differentiation of CD4 memory T cells defined by expression of CCR7 and CD27, J. Immunol 175, 6489-6497 (2005). [PubMed: 16272303]

22. Snyder ME, Finlayson MO, Connors TJ, Dogra P, Senda T, Bush E, Carpenter D, Marboe C, Benvenuto L, Shah L, Robbins H, Hook JL, Sykes M, D’Ovidio F, Bacchetta M, Sonett JR, Lederer DJ, Arcasoy S, Sims PA, Farber DL, Generation and persistence of human tissue-resident memory T cells in lung transplantation, Sci Immunol 4 (2019), doi:10.1126/sciimmunol.aav5581. 
23. Reyes R, Cardeñes B, Machado-Pineda Y, Cabañas C, Tetraspanin CD9: A Key Regulator of Cell Adhesion in the Immune System, Front Immunol 9, 863 (2018). [PubMed: 29760699]

24. Zhang J, Dong J, Gu H, Yu S, Zhang X, Gou Y, Xu W, Burd A, Huang L, Miyado K, Huang Y, Chan HC, CD9 is critical for cutaneous wound healing through JNK signaling, J. Invest. Dermatol 132, 226-236 (2012). [PubMed: 21881583]

25. Mackay LK, Rahimpour A, Ma JZ, Collins N, Stock AT, Hafon M-L, Vega-Ramos J, Lauzurica P, Mueller SN, Stefanovic T, Tscharke DC, Heath WR, Inouye M, Carbone FR, Gebhardt T, The developmental pathway for CD103(+)CD8+ tissue-resident memory T cells of skin, Nat. Immunol 14, 1294-1301 (2013). [PubMed: 24162776]

26. Mohammed J, Beura LK, Bobr A, Astry B, Chicoine B, Kashem SW, Welty NE, Igyártó BZ, Wijeyesinghe S, Thompson EA, Matte C, Bartholin L, Kaplan A, Sheppard D, Bridges AG, Shlomchik WD, Masopust D, Kaplan DH, Stromal cells control the epithelial residence of DCs and memory T cells by regulated activation of TGF- $\beta$, Nat. Immunol 17, 414-421 (2016). [PubMed: 26901152]

27. Falanga V, Qian SW, Danielpour D, Katz MH, Roberts AB, Sporn MB, Hypoxia upregulates the synthesis of TGF-beta 1 by human dermal fibroblasts, J. Invest. Dermatol 97, 634-637 (1991). [PubMed: 1940433]

28. McCully ML, Ladell K, Andrews R, Jones RE, Miners KL, Roger L, Baird DM, Cameron MJ, Jessop ZM, Whitaker IS, Davies EL, Price DA, Moser B, CCR8 Expression Defines TissueResident Memory T Cells in Human Skin, J. Immunol 200, 1639-1650 (2018). [PubMed: 29427415]

29. Mackay LK, Wynne-Jones E, Freestone D, Pellicci DG, Mielke LA, Newman DM, Braun A, Masson F, Kallies A, Belz GT, Carbone FR, T-box Transcription Factors Combine with the Cytokines TGF- $\beta$ and IL-15 to Control Tissue-Resident Memory T Cell Fate, Immunity 43, 11011111 (2015). [PubMed: 26682984]

30. Pan Y, Tian T, Park CO, Lofftus SY, Mei S, Liu X, Luo C, O’Malley JT, Gehad A, Teague JE, Divito SJ, Fuhlbrigge R, Puigserver P, Krueger JG, Hotamisligil GS, Clark RA, Kupper TS, Survival of tissue-resident memory $\mathrm{T}$ cells requires exogenous lipid uptake and metabolism, Nature 543, 252-256 (2017). [PubMed: 28219080]

31. Duhen T, Geiger R, Jarrossay D, Lanzavecchia A, Sallusto F, Production of interleukin 22 but not interleukin 17 by a subset of human skin-homing memory T cells, Nat. Immunol 10, 857-863 (2009). [PubMed: 19578369]

32. Trifari S, Kaplan CD, Tran EH, Crellin NK, Spits H, Identification of a human helper T cell population that has abundant production of interleukin 22 and is distinct from $\mathrm{T}(\mathrm{H})-17, \mathrm{~T}(\mathrm{H}) 1$ and T(H)2 cells, Nat. Immunol 10, 864-871 (2009). [PubMed: 19578368]

33. Gieseck RL, Wilson MS, Wynn TA, Type 2 immunity in tissue repair and fibrosis, Nat. Rev. Immunol 18, 62-76 (2018). [PubMed: 28853443]

34. Sonnenberg GF, Fouser LA, Artis D, Border patrol: regulation of immunity, inflammation and tissue homeostasis at barrier surfaces by IL-22, Nat. Immunol 12, 383-390 (2011). [PubMed: 21502992]

35. Taniguchi T, Woodward AM, Magnelli P, McColgan NM, Lehoux S, Jacobo SMP, Mauris J, Argüeso P, N-Glycosylation affects the stability and barrier function of the MUC16 mucin, J. Biol. Chem 292, 11079-11090 (2017). [PubMed: 28487369]

36. Gipson IK, Spurr-Michaud S, Tisdale A, Menon BB, Comparison of the transmembrane mucins MUC1 and MUC16 in epithelial barrier function, PLoS ONE 9, e100393 (2014). [PubMed: 24968021]

37. McLeod K, Walker JT, Hamilton DW, Galectin-3 regulation of wound healing and fibrotic processes: insights for chronic skin wound therapeutics, J Cell Commun Signal 12, 281-287 (2018). [PubMed: 29372416]

38. Xu M, Lu H, Lee Y-H, Wu Y, Liu K, Shi Y, An H, Zhang J, Wang X, Lai Y, Dong C, An Interleukin-25-Mediated Autoregulatory Circuit in Keratinocytes Plays a Pivotal Role in Psoriatic Skin Inflammation, Immunity 48, 787-798.e4 (2018). [PubMed: 29653697] 
39. Sato T, Kirimura Y, Mori Y, The co-culture of dermal fibroblasts with human epidermal keratinocytes induces increased prostaglandin E2 production and cyclooxygenase 2 activity in fibroblasts, J. Invest. Dermatol 109, 334-339 (1997). [PubMed: 9284101]

40. Meller S, Di Domizio J, Voo KS, Friedrich HC, Chamilos G, Ganguly D, Conrad C, Gregorio J, Le Roy D, Roger T, Ladbury JE, Homey B, Watowich S, Modlin RL, Kontoyiannis DP, Liu Y-J, Arold ST, Gilliet M, T(H)17 cells promote microbial killing and innate immune sensing of DNA via interleukin 26, Nat. Immunol 16, 970-979 (2015). [PubMed: 26168081]

41. Woetmann A, Alhede M, Dabelsteen S, Bjarnsholt T, Rybtke M, Nastasi C, Krejsgaard T, Andersen MH, Bonefeld CM, Geisler C, Givskov M, Odum N, Interleukin-26 (IL-26) is a novel anti-microbial peptide produced by $\mathrm{T}$ cells in response to staphylococcal enterotoxin, Oncotarget 9, 19481-19489 (2018). [PubMed: 29731960]

42. Venturi V, Kedzierska K, Tanaka MM, Turner SJ, Doherty PC, Davenport MP, Method for assessing the similarity between subsets of the T cell receptor repertoire, J. Immunol. Methods 329, 67-80 (2008). [PubMed: 18001765]

43. Mori L, Lepore M, De Libero G, The Immunology of CD1- and MR1-Restricted T Cells, Annual Review of Immunology 34, 479-510 (2016).

44. Förster R, Schubel A, Breitfeld D, Kremmer E, Renner-Müller I, Wolf E, Lipp M, CCR7 coordinates the primary immune response by establishing functional microenvironments in secondary lymphoid organs, Cell 99, 23-33 (1999). [PubMed: 10520991]

45. Wang CK, Nelson CF, Brinkman AM, Miller AC, Hoeffler WK, Spontaneous cell sorting of fibroblasts and keratinocytes creates an organotypic human skin equivalent, J. Invest. Dermatol 114, 674-680 (2000). [PubMed: 10733672]

46. Beura LK, Wijeyesinghe S, Thompson EA, Macchietto MG, Rosato PC, Pierson MJ, Schenkel JM, Mitchell JS, Vezys V, Fife BT, Shen S, Masopust D, T Cells in Nonlymphoid Tissues Give Rise to Lymph-Node-Resident Memory T Cells, Immunity 48, 327-338.e5 (2018). [PubMed: 29466758]

47. Klicznik MM, Benedetti A, Stoecklinger A, Campbell DJ, Gratz IK, Circulating CD4+ memory T cells give rise to a CD69+ resident memory $\mathrm{T}$ cell population in non-inflamed human skin, bioRxiv, 490094 (2018).

48. C. M. dos S. Camargo, Brotas AM, Ramos-e-Silva M, Carneiro S, Isomorphic phenomenon of Koebner: facts and controversies, Clin. Dermatol 31, 741-749 (2013). [PubMed: 24160280]

49. Weiss G, Shemer A, Trau H, The Koebner phenomenon: review of the literature, J Eur Acad Dermatol Venereol 16, 241-248 (2002). [PubMed: 12195563]

50. Lebas E, Libon F, Nikkels AF, Koebner Phenomenon and Mycosis Fungoides, Case Rep Dermatol 7, 287-291 (2015). [PubMed: 26557075]

51. Toulon A, Breton L, Taylor KR, Tenenhaus M, Bhavsar D, Lanigan C, Rudolph R, Jameson J, Havran WL, A role for human skin-resident T cells in wound healing, J Exp Med 206, 743-750 (2009). [PubMed: 19307328]

52. Ferrante CJ, Leibovich SJ, Regulation of Macrophage Polarization and Wound Healing, Adv Wound Care (New Rochelle) 1, 10-16 (2012). [PubMed: 24527272]

53. Wolk K, Witte E, Wallace E, Döcke W-D, Kunz S, Asadullah K, Volk H-D, Sterry W, Sabat R, IL-22 regulates the expression of genes responsible for antimicrobial defense, cellular differentiation, and mobility in keratinocytes: a potential role in psoriasis, Eur. J. Immunol 36, 1309-1323 (2006). [PubMed: 16619290]

54. Dalessandri T, Crawford G, Hayes M, Seoane R. Castro, Strid J, IL-13 from intraepithelial lymphocytes regulates tissue homeostasis and protects against carcinogenesis in the skin, Nat Commun 7, 12080 (2016). [PubMed: 27357235]

55. Kim BS, Innate lymphoid cells in the skin, J. Invest. Dermatol 135, 673-678 (2015). [PubMed: 25339380]

56. Rodriguez R. Sanchez, Pauli ML, Neuhaus IM, Yu SS, Arron ST, Harris HW, Yang SH-Y, Anthony BA, Sverdrup FM, Krow-Lucal E, Mackenzie TC, Johnson DS, Meyer EH, Löhr A, Hsu A, Koo J, Liao W, Gupta R, Debbaneh MG, Butler D, Huynh M, Levin EC, Leon A, Hoffman WY, McGrath MH, Alvarado MD, Ludwig CH, Truong H-A, Maurano MM, Gratz IK, Abbas AK, Rosenblum MD, Memory regulatory T cells reside in human skin, J. Clin. Invest 124, 1027-1036 (2014). [PubMed: 24509084] 
57. Gerlach C, Moseman EA, Loughhead SM, Alvarez D, Zwijnenburg AJ, Waanders L, Garg R, de la Torre JC, von Andrian UH, The Chemokine Receptor CX3CR1 Defines Three AntigenExperienced CD8 T Cell Subsets with Distinct Roles in Immune Surveillance and Homeostasis, Immunity 45, 1270-1284 (2016). [PubMed: 27939671]

58. Voillet V, Buggert M, Slichter CK, Berkson JD, Mair F, Addison MM, Dori Y, Nadolski G, Itkin MG, Gottardo R, Betts MR, Prlic M, Human MAIT cells exit peripheral tissues and recirculate via lymph in steady state conditions, JCI Insight 3 (2018), doi:10.1172/jci.insight.98487.

59. Ritchie ME, Phipson B, Wu D, Hu Y, Law CW, Shi W, Smyth GK, limma powers differential expression analyses for RNA-sequencing and microarray studies, Nucleic Acids Res 43, e47 (2015). [PubMed: 25605792]

60. Robins HS, Campregher PV, Srivastava SK, Wacher A, Turtle CJ, Kahsai O, Riddell SR, Warren $\mathrm{EH}$, Carlson CS, Comprehensive assessment of T-cell receptor beta-chain diversity in alphabeta T cells, Blood 114, 4099-4107 (2009). [PubMed: 19706884]

61. Merkley MA, Hildebrandt E, Podolsky RH, Arnouk H, Ferris DG, Dynan WS, Stöppler H, Largescale analysis of protein expression changes in human keratinocytes immortalized by human papilloma virus type 16 E6 and E7 oncogenes, Proteome Sci 7, 29 (2009). [PubMed: 19698150]

62. Daley JM, Thomay AA, Connolly MD, Reichner JS, Albina JE, Use of Ly6G-specific monoclonal antibody to deplete neutrophils in mice, J. Leukoc. Biol 83, 64-70 (2008). [PubMed: 17884993]

63. Racki WJ, Covassin L, Brehm M, Pino S, Ignotz R, Dunn R, Laning J, Graves SK, Rossini AA, Shultz LD, Greiner DL, NOD-scid IL2rynull (NSG) Mouse Model of Human Skin Transplantation and Allograft Rejection, Transplantation 89, 527-536 (2010). [PubMed: 20134397]

64. Gratz IK, Rosenblum MD, Maurano MM, Paw JS, Truong H-A, Marshak-Rothstein A, Abbas AK, Cutting edge: Self-antigen controls the balance between effector and regulatory T cells in peripheral tissues, J. Immunol 192, 1351-1355 (2014). [PubMed: 24442443] 

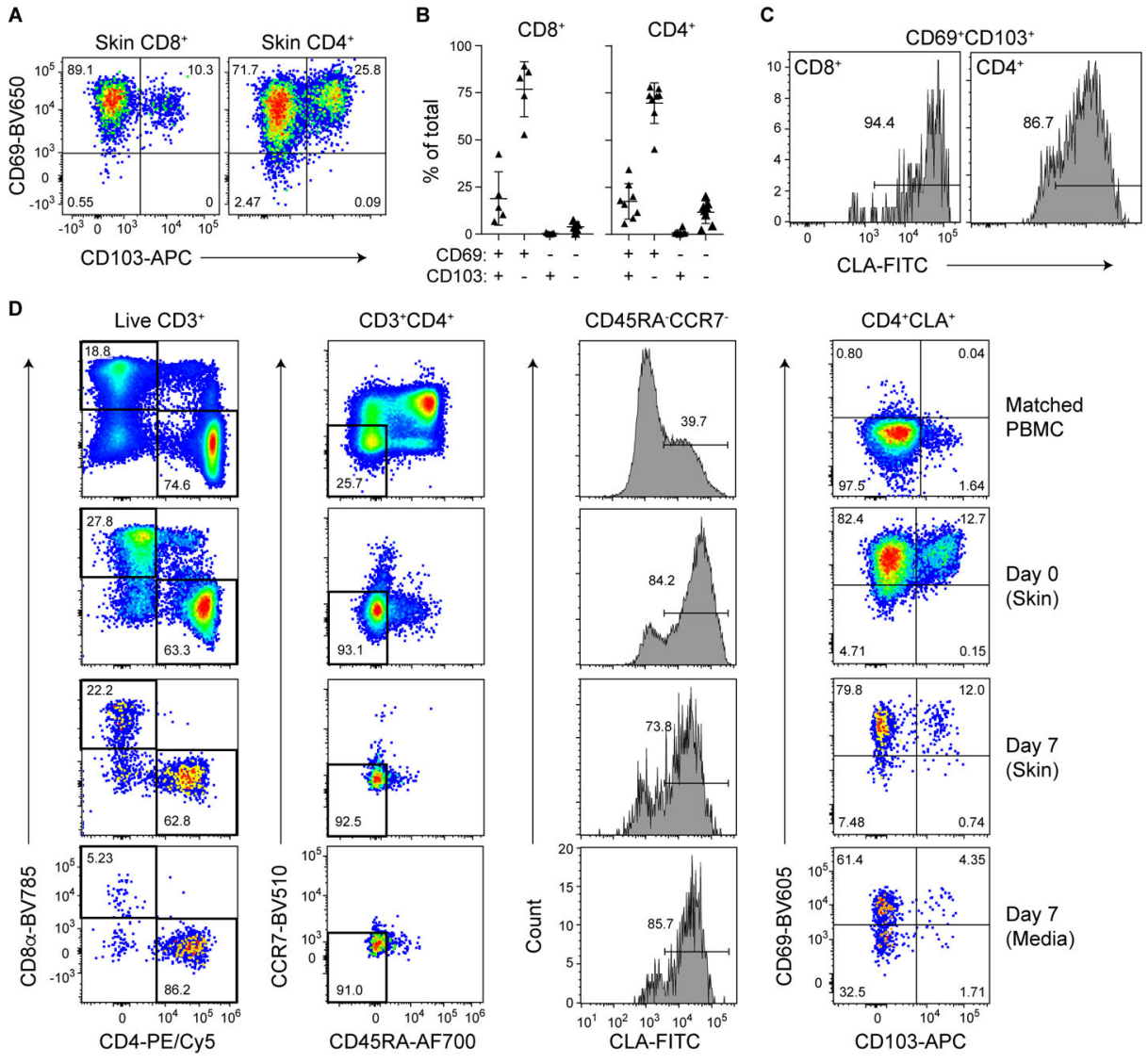

$E$
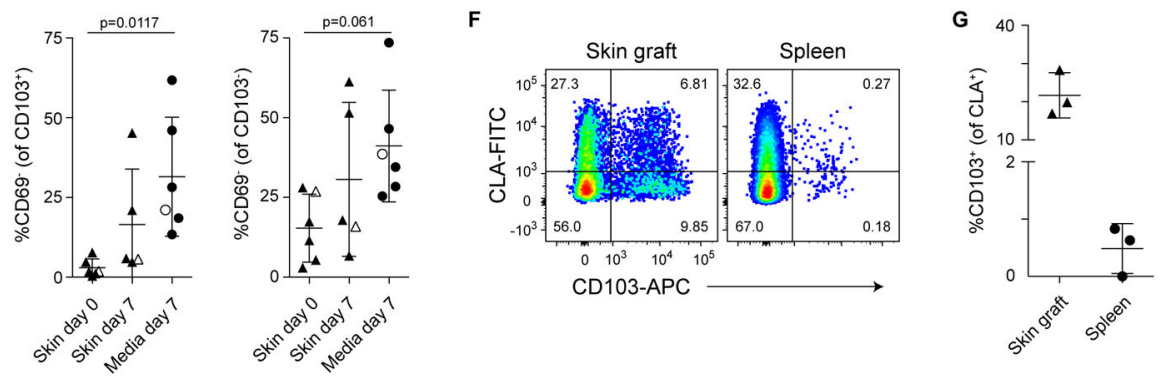

Figure 1: $\mathrm{CD}^{+} \mathrm{CLA}^{+} \mathrm{CD}_{103}^{+} \mathrm{T}$ cells downregulate $\mathrm{CD69}$ and exit the skin.

(A) Representative flow cytometry analysis of CD69 and CD103 expression by live gated $\mathrm{CD}^{+}$and $\mathrm{CD} 4^{+} \mathrm{T}$ cells from human skin. (B) Graphical summary of the proportions of CD69- and CD103-defined $\mathrm{T}$ cell populations among $\mathrm{CD} 8^{+}$and $\mathrm{CD} 4^{+}$skin $\mathrm{T}$ cells. $(\mathbf{C})$ Representative flow cytometry analysis of CLA expression by live gated $\mathrm{CD} 103^{+} \mathrm{CD} 69^{+}$ $\mathrm{T}_{\mathrm{RM}}$ in human skin. (D) Human skin was adhered to tissue culture plates and cultured for 7 days submerged in media. The ratio of $\mathrm{CD}^{+}$and $\mathrm{CD} 8^{+} \mathrm{T}$ cells and the expression of CLA and $\mathrm{CD} 103$ by $\mathrm{T}$ cells in the indicated samples were analyzed by flow cytometry.

Representative data ( $\mathrm{N}=4)$. (E) Graphical summary of the proportion of $\mathrm{CD}^{-} 9^{-}$cells among $\mathrm{CD}_{103}{ }^{+}$or $\mathrm{CD}_{103}{ }^{-}$live gated $\mathrm{CD} 45 \mathrm{RA}^{-} \mathrm{CD} 4^{+} \mathrm{CLA}^{+} \mathrm{T}$ cells from the indicated samples.

Open symbols represent data from a subject with mammary carcinoma but no skin condition. Significance determined by one-way repeated measures ANOVA with Tukey's post-test for pairwise comparisons. (F) Three 8mm-punch biopsies of healthy human skin 
per animal $(\mathrm{N}=3)$ were placed on the back of NSG mice and grafts as well as spleens were analyzed by flow cytometry 50 days later. Representative flow cytometry analysis of CLA and $\mathrm{CD} 103$ expression by live gated human $\mathrm{CD} 45^{+} \mathrm{CD} 3{ }^{+} \mathrm{CD} 4{ }^{+} \mathrm{CD} 25^{-} \mathrm{CD} 45 \mathrm{RA}^{-} \mathrm{T}$ cells. (G) Graphical summary showing CD103 expression by live gated human $\mathrm{CD} 5^{+} \mathrm{CD} 3^{+} \mathrm{CD}^{+} \mathrm{CD} 25^{-} \mathrm{CD} 45 \mathrm{RA}^{-} \mathrm{CLA}^{+} \mathrm{T}$ cells from skin grafts and spleens of skingrafted NSG mice. 
A

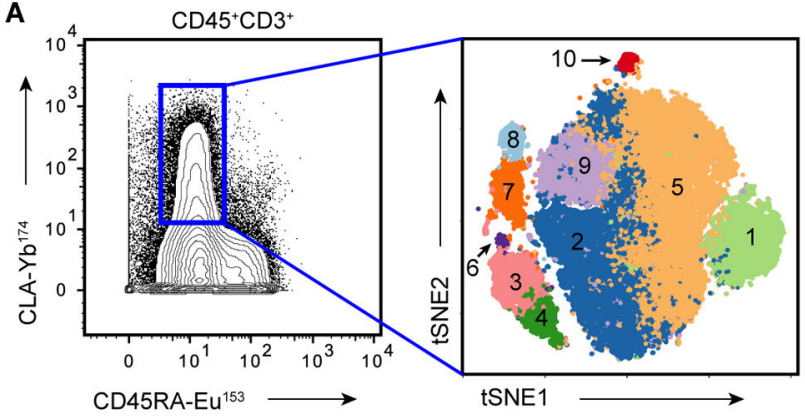

C

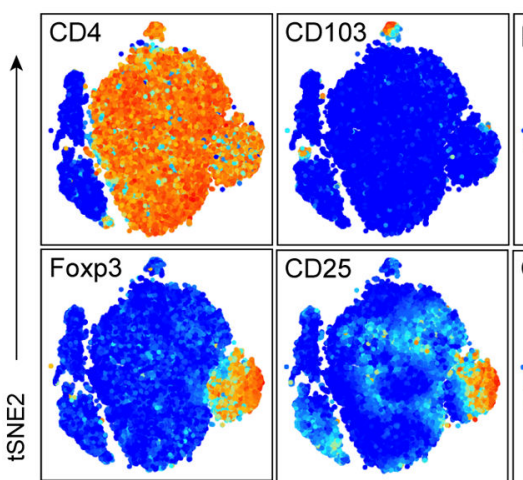

tSNE1

B

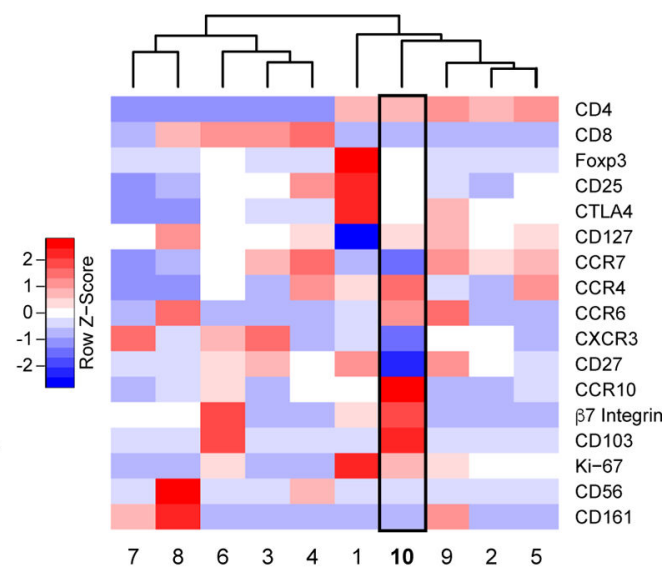

Figure 2: $\mathrm{CD4}^{+} \mathrm{CLA}^{+} \mathrm{CD}{ }^{+}{ }^{+} \mathrm{T}$ cells constitute a unique cell population in human blood.

(A) (Left), Mass cytometry analysis of CD45RA and CLA expression by live gated $\mathrm{CD}^{+} \mathrm{CD}^{4} 5^{+} \mathrm{PBMC}$ showing the gate used to define $\mathrm{CD}^{+} \mathrm{CLA}^{+} \mathrm{T}$ cells for subsequent clustering analysis. (Right), t-SNE analysis and clustering of $\mathrm{CD}^{+} \mathrm{CLA}^{+} \mathrm{T}$ cells from blood of 5 healthy donors based on expression of CD4, CD8, CCR7, CD103, $\beta 7$ Integrin, CXCR3, CCR6, CCR4, CCR10, Foxp3, CD27, $\beta 7$ integrin, CD25, CD161, and CD56. (B) Heat map showing relative expression of the indicated markers in each of the $\mathrm{CD}^{+} \mathrm{CLA}^{+}$cell clusters. (C) t-SNE analysis of $\mathrm{CD}^{+} \mathrm{CLA}^{+} \mathrm{T}$ cells overlaid with relative expression of the indicated markers. 

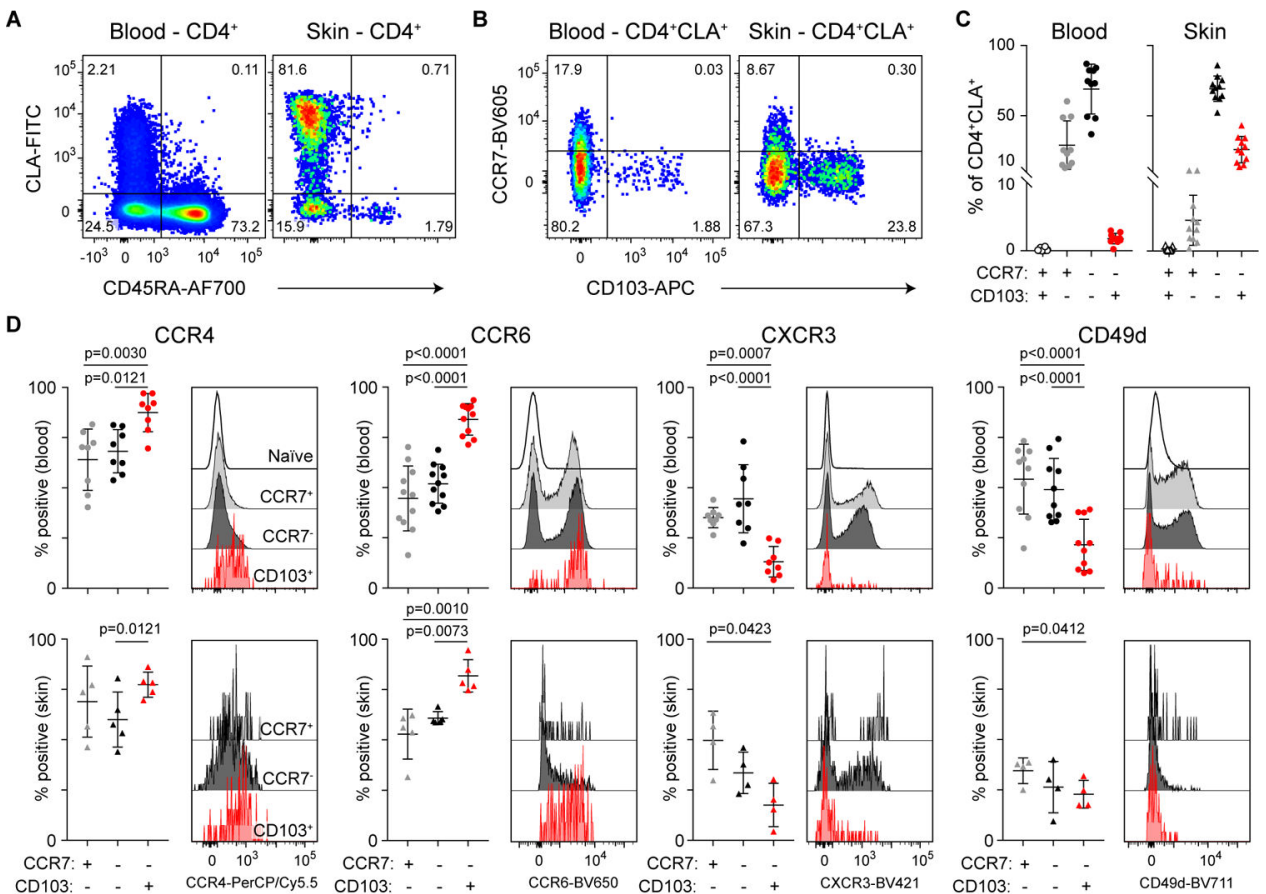

E
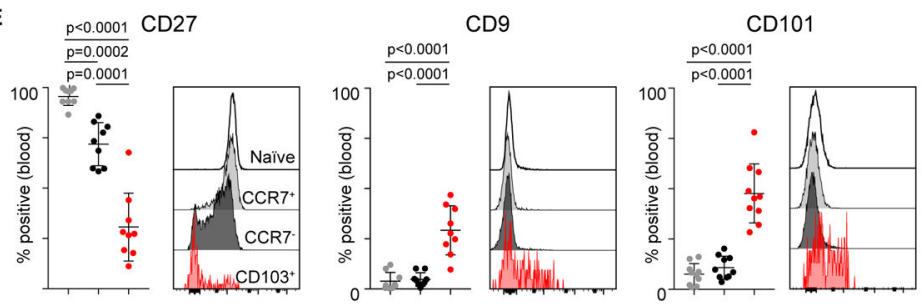

CD69
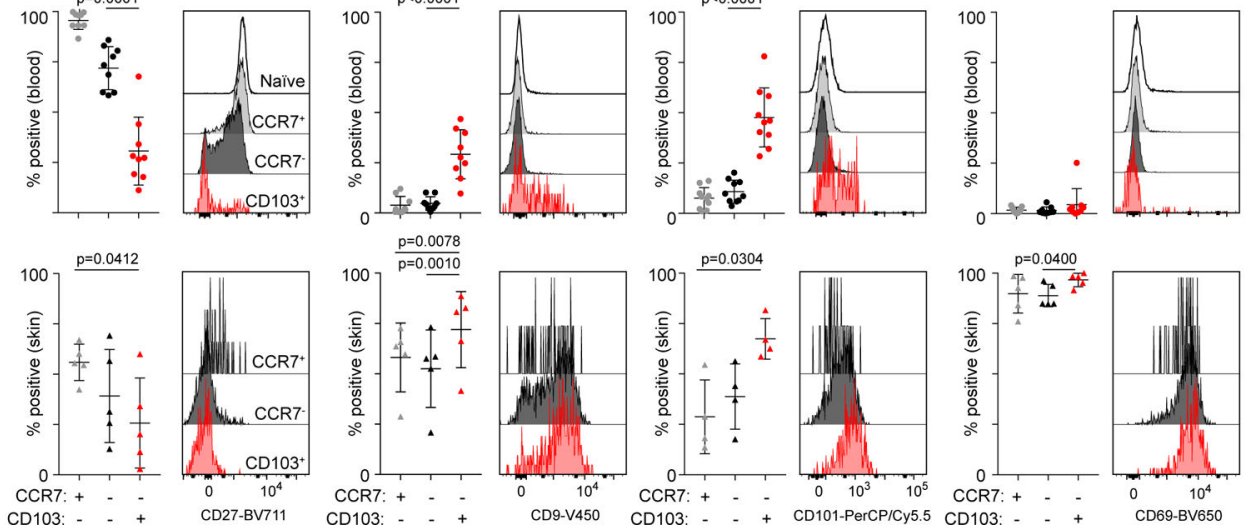

Figure 3: Shared phenotype of $\mathrm{CD4}^{+} \mathrm{CLA}^{+} \mathrm{CD103}^{+} \mathrm{T}$ cells from human blood and skin.

(A) Representative flow cytometry analysis of CD45RA and CLA expression by live gated $\mathrm{CD}^{+} \mathrm{T}$ cells from blood and skin of healthy donors. (B) Representative flow cytometry analysis of CCR 7 and CD103 expression by live gated CD4 ${ }^{+} \mathrm{CD} 45 \mathrm{RA}^{-} \mathrm{CLA}^{+}$memory $\mathrm{T}$ cells from blood and skin of healthy donors. (C) Graphical summary of the proportions of CCR7- and CD103-defined $\mathrm{T}$ cell populations among CD4 ${ }^{+} \mathrm{CD} 45 \mathrm{RA}^{-} \mathrm{CLA}^{+}$cells from blood and skin. (D,E) Representative flow cytometry analysis and graphical summary of expression of the indicated markers by $\mathrm{CD}^{+} \mathrm{T}$ cell populations in the blood and skin as indicated. Significance determined by one-way repeated measures ANOVA with Tukey's post-test for pairwise comparisons. 


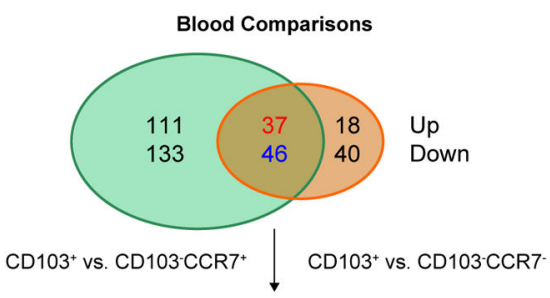

CD103+ Gene Signature

B

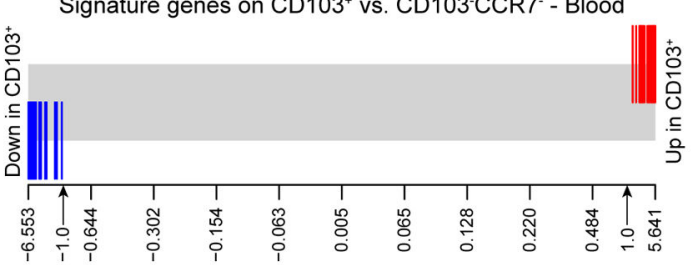

Signature genes on $\mathrm{CD}_{103^{+}}$vs. CD103-CCR7- Skin

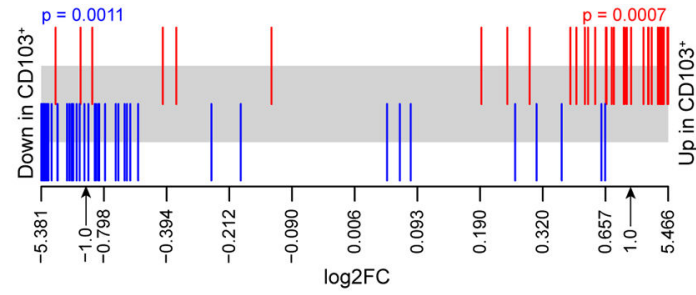

D

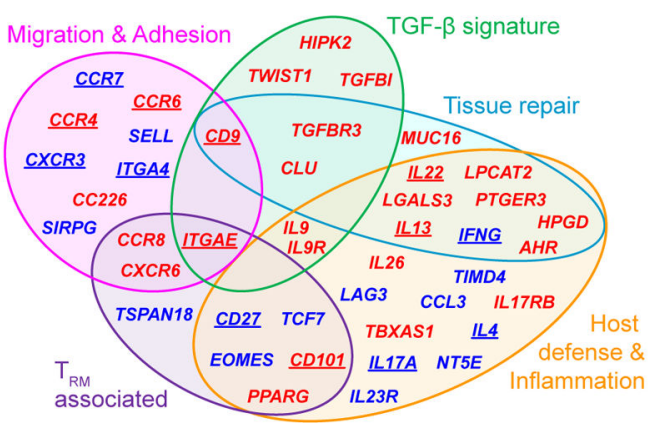

C

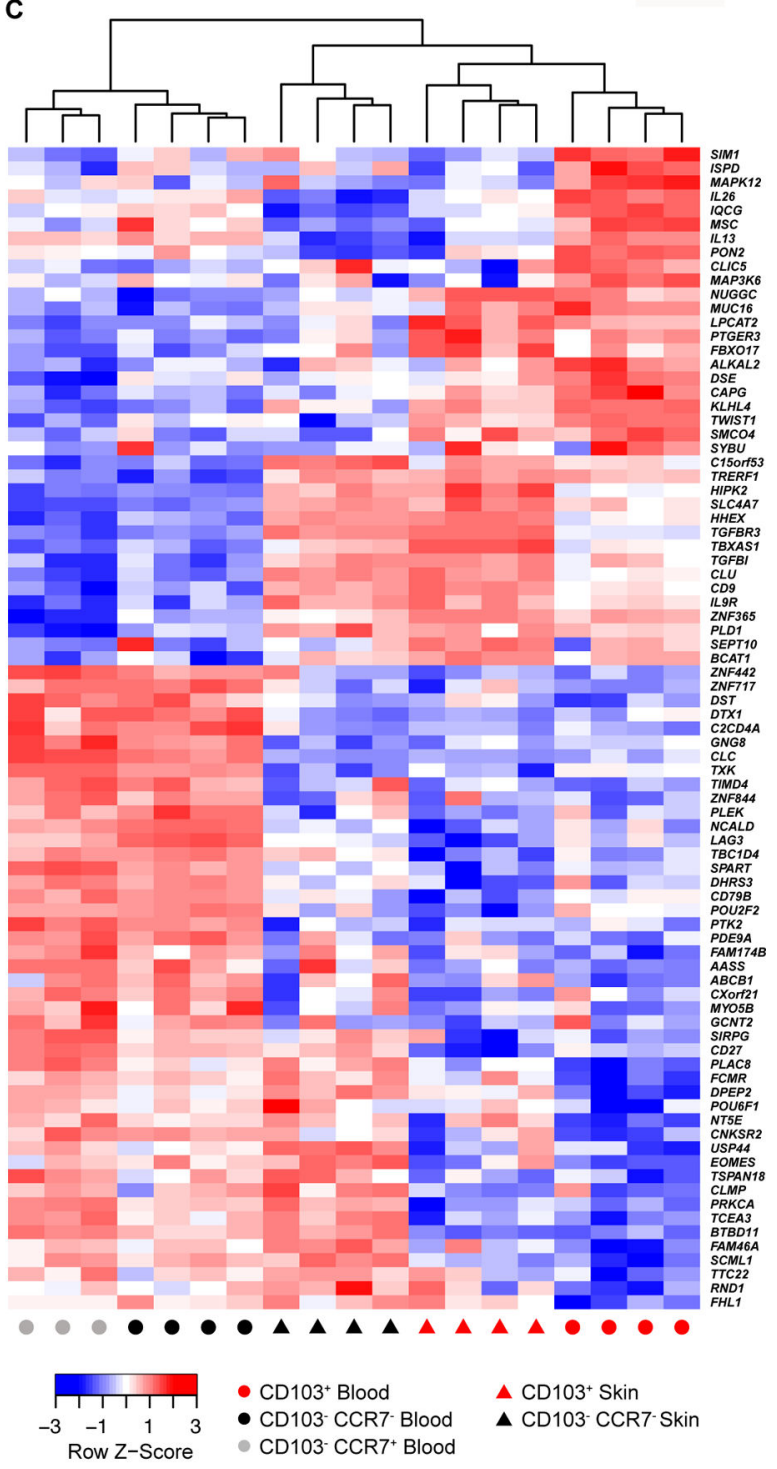

Figure 4: $\mathrm{CD4}^{+} \mathrm{CLA}^{+} \mathrm{CD103}^{+} \mathrm{T}$ cells from human blood and skin share a transcriptional profile. Whole transcriptome profiling by RNA-sequencing was performed on sorted CLA ${ }^{+} \mathrm{T}$ cell subsets from blood or skin. (A) Venn diagram showing the number of significantly differentially expressed (DE) genes (FDR $<0.05$ and $\log 2$ fold-change $>1$ ) between CLA ${ }^{+} \mathrm{CD}_{103}{ }^{+} \mathrm{T}$ cells and either $\mathrm{CLA}^{+} \mathrm{CD} 103^{-} \mathrm{CCR}^{+}$or $\mathrm{CLA}^{+} \mathrm{CD} 103^{-}{ }^{-} \mathrm{CCR} 7^{-} \mathrm{T}$ cells as indicated. The overlapping 83 genes were designated the $\mathrm{CD} 103^{+}$gene signature. (B) Barcode plot showing the distribution of the $\mathrm{CD}_{103^{+}}$signature genes (red=up- blue=downregulated in $\mathrm{CD}_{103^{+}}$) relative to gene expression changes comparing $\mathrm{CD}_{103^{+}}$and

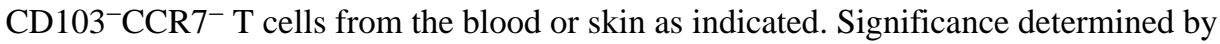
rotation gene set testing for linear models. (C) Heat map and hierarchical clustering of RNA-seq samples from the indicated blood and skin cell populations based on the CD103+ gene signature. (D) Venn diagram showing functional annotation of key genes up- or downregulated by $\mathrm{CLA}^{+} \mathrm{CD} 103^{+} \mathrm{T}$ cells in blood or skin identified in our phenotypic, functional, and transcriptional analyses. Category names were assigned based on described functions of 
the indicated genes in the published literature. Underlined gene names indicate proteins whose expression pattern was validated by flow cytometry in Figs 3 and 5. 


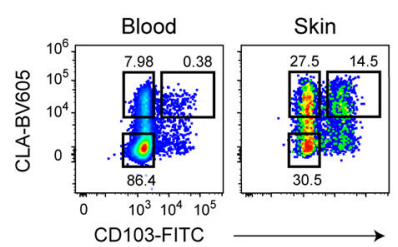

B

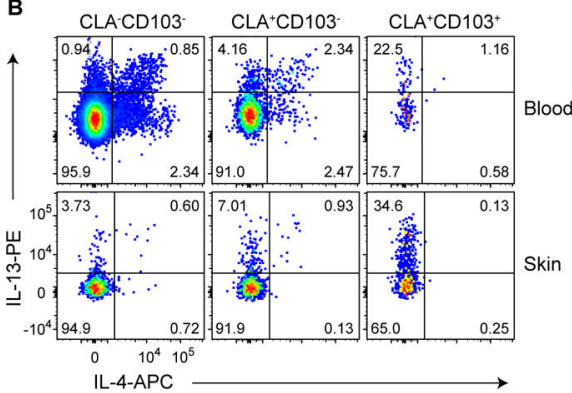

C

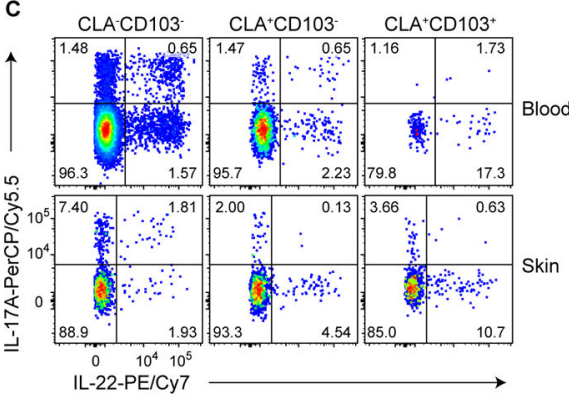

D

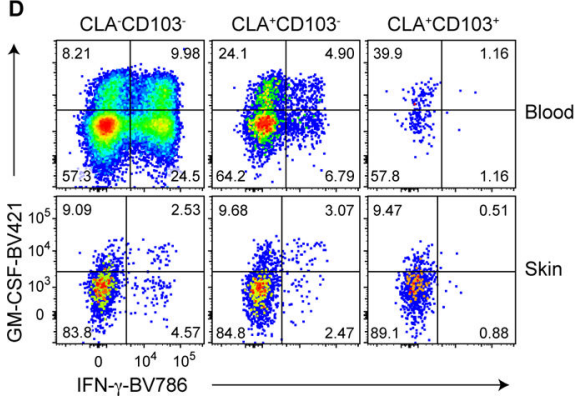

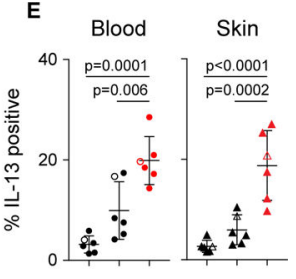
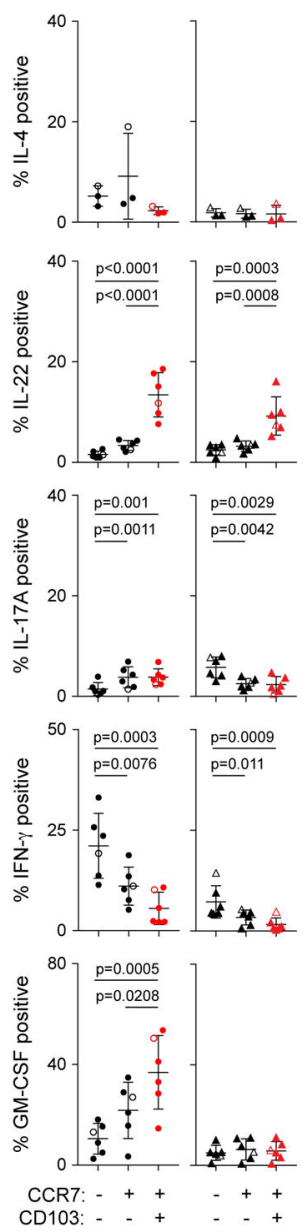

Figure 5: $\mathrm{CD4}^{+} \mathrm{CLA}^{+} \mathrm{CD103}^{+} \mathrm{T}$ cells from human blood and skin share a functional profile. (A) Representative flow cytometry analysis of CD45RA and CLA expression by live gated CD4 ${ }^{+} \mathrm{T}$ cells from blood and skin of healthy donors. (B,C,D) Representative flow cytometry analysis of indicated CLA/CD103 subpopulations of blood and skin $\mathrm{CD}^{+}{ }^{+} \mathrm{CD} 45 \mathrm{RA}^{-}$cells producing IL-13, IL-4, IL-22, IL-17A, IFN- $\gamma$ and GM-CSF as indicated upon ex vivo stimulation with PMA/ionomycin and intracellular cytokine staining. (E) Graphical summary of the proportions of $\mathrm{CLA}^{-} \mathrm{CD}_{103}{ }^{-}, \mathrm{CLA}^{+} \mathrm{CD}_{103}{ }^{-}$, and $\mathrm{CLA}^{+} \mathrm{CD}_{103}{ }^{+}$ $\mathrm{CD}^{+}{ }^{+} \mathrm{CD} 45 \mathrm{RA}^{-}$cells producing cytokines as indicated. Open symbols represent data from a subject with mammary carcinoma. Significance determined by one-way repeated measures ANOVA with Tukey's post-test for pairwise comparisons. 
A

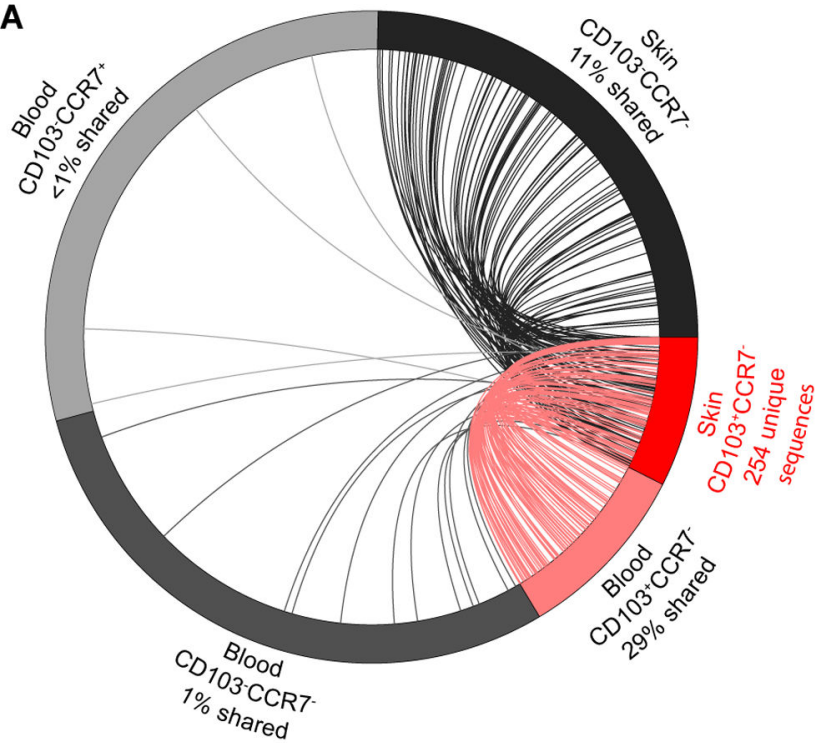

B

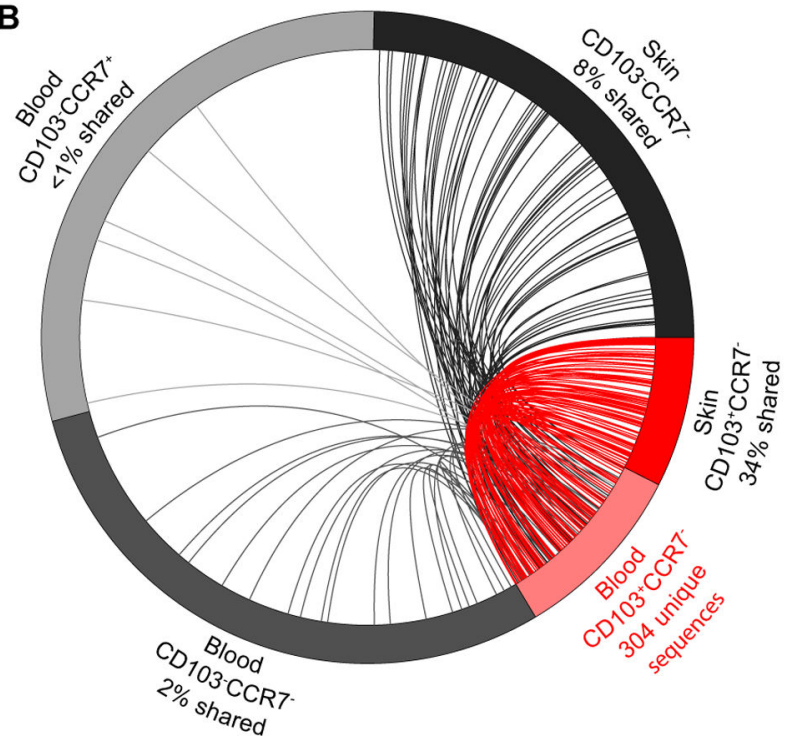

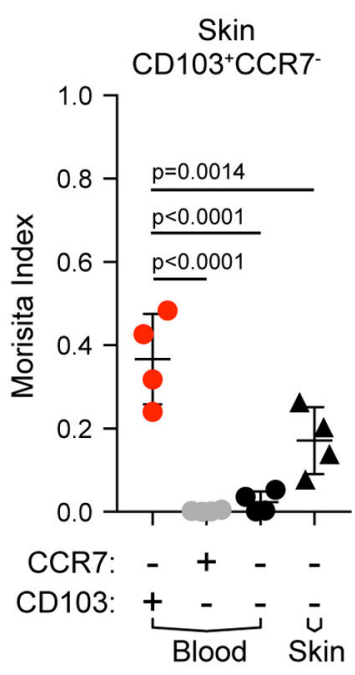

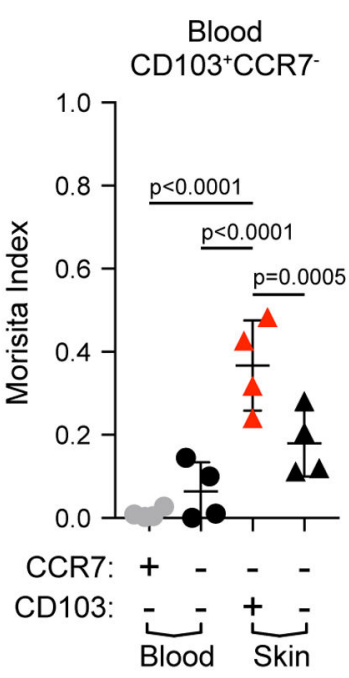

Figure 6: $\mathrm{CD4}^{+} \mathrm{CLA}^{+} \mathrm{CD} 103^{+} \mathrm{T}$ cells in skin and blood are clonally related.

TCR $\beta$-sequencing was performed on sorted $\mathrm{CLA}^{+}$memory $\mathrm{CD}^{+} \mathrm{T}$ cell subsets (as in Fig. 4) from blood and skin sorted based on expression of CD103 and CCR7 as indicated. (A) (left) Circle plot of unique productive TCR $\beta$ sequences from each of the indicated populations of $\mathrm{CLA}^{+} \mathrm{T}$ cells from one representative donor (donor 1). Connections highlight sequences from skin $\mathrm{CLA}^{+} \mathrm{CD}_{103}{ }^{+}$cells found in each of the other populations. For visualization, sequences were downsampled (weighted for relative abundance) for populations containing >1000 unique sequences. (right) Graphical summary of the Morisita index as a measure of TCR repertoire similarity over all productive rearrangements between $\mathrm{CLA}^{+} \mathrm{CD} 103^{+}$cells in the blood and each of the indicated populations across all 4 donors examined. (B) Circle plot (left) and graphical summary of the Morisita index (right) as in $\mathbf{A}$ using $\mathrm{CLA}^{+} \mathrm{CD}_{103}{ }^{+} \mathrm{T}$ cells from blood as the reference population. Significance determined by one-way ANOVA with Dunnett's multiple comparisons test. 


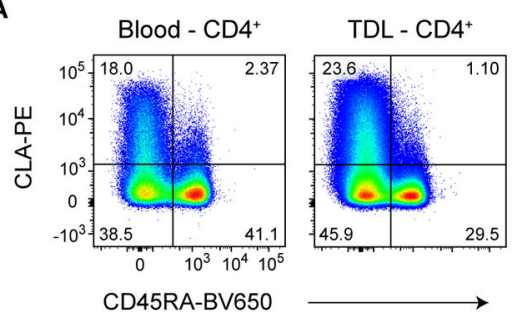

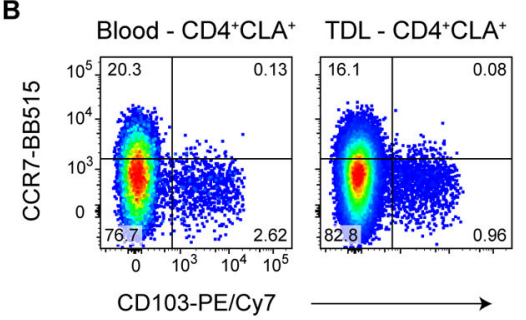
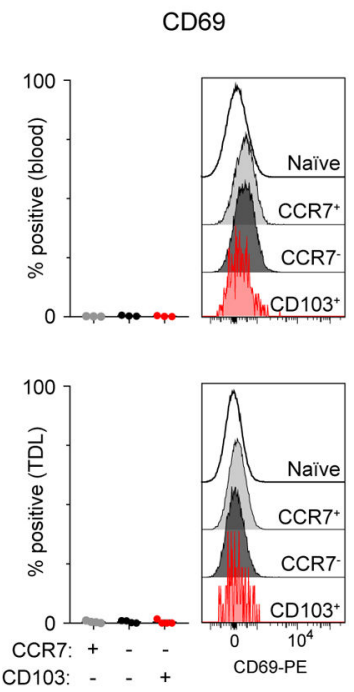
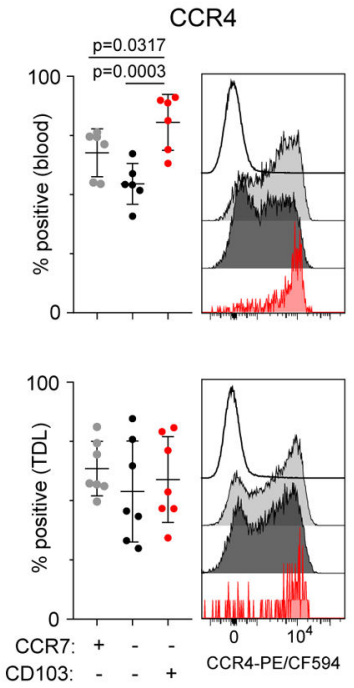

C

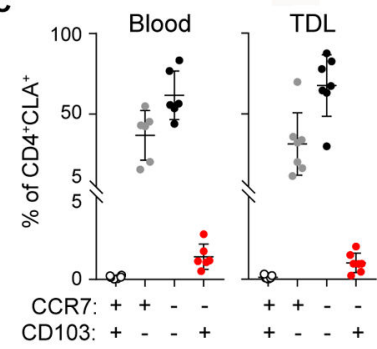

CD27
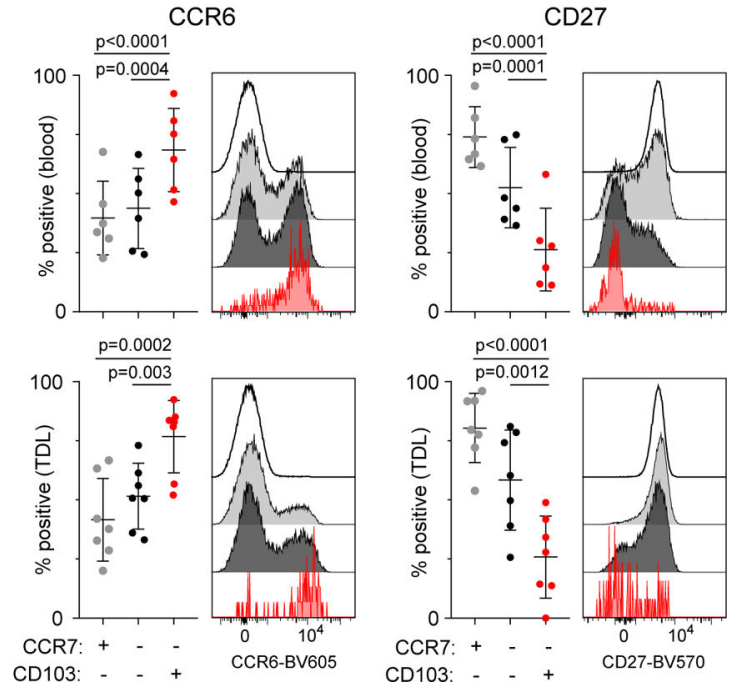

Figure 7: $\mathrm{CD4}^{+} \mathrm{CLA}^{+} \mathrm{CD} \mathrm{O3}^{+} \mathrm{T}$ cells are present in human lymph.

(A) Representative flow cytometry analysis of CD45RA and CLA expression by live gated $\mathrm{CD} 4^{+} \mathrm{T}$ cells from blood and TDL. (B) Representative flow cytometry analysis of CCR7 and $\mathrm{CD} 103$ expression by live gated $\mathrm{CD}^{+}{ }^{+} \mathrm{CD} 45 \mathrm{RA}^{-} \mathrm{CLA}^{+}$memory $\mathrm{T}$ cells from blood and TDL. (C) Graphical summary of the proportions of CCR7- and CD103-defined T cell populations among $\mathrm{CD}^{+}{ }^{+} \mathrm{CD} 45 \mathrm{RA}^{-} \mathrm{CLA}^{+}$cells from blood and TDL. (D) Representative flow cytometry analysis and graphical summary of expression of the indicated markers by $\mathrm{CD}^{+} \mathrm{T}$ cell populations in the blood and TDL as indicated. Significance determined by one-way repeated measures ANOVA with Tukey's post-test for pairwise comparisons. 


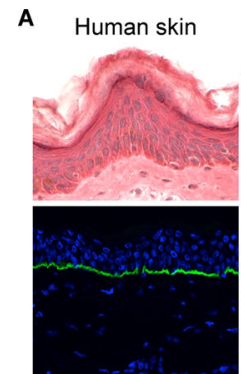

c

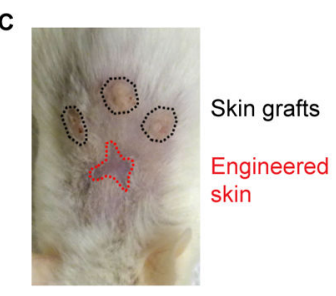

F

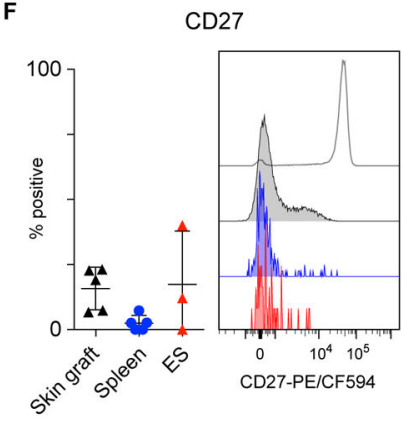

G

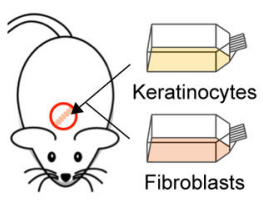

Generate ES

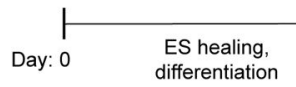

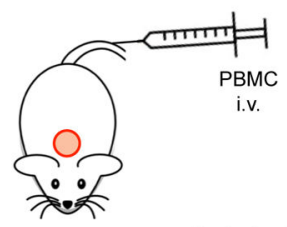

Inject PBMC
Murine skin

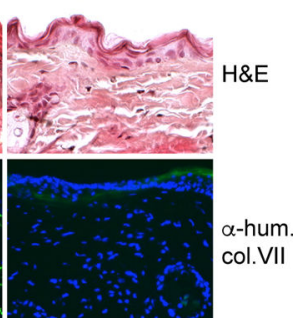

D

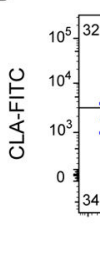

B

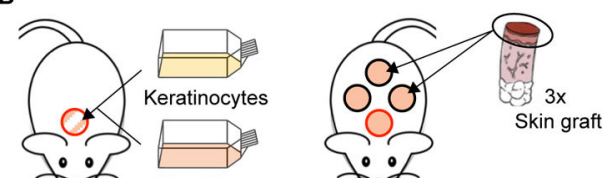

Analysis of skin grafts,
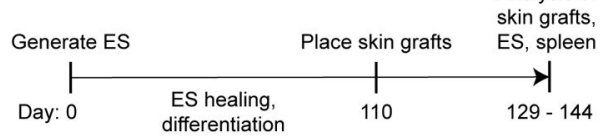

Figure 8: $\mathrm{CD}^{+} \mathrm{CLA}^{+} \mathrm{CD} 103^{+} \mathrm{T}_{\mathrm{RM}}$ can exit the skin and reseed distant skin sites in a xenograft model.

(A) In vitro expanded human keratinocytes and fibroblasts were grafted onto the backs of NSG mice using a grafting chamber. After 99 days of healing and differentiation, the engineered skin (ES) or adjacent murine skin were excised, frozen in OCT and stained either with hematoxylin and eosin (left) or with anti-human type VII collagen prior to immunofluorescence analysis (right). Human skin from a healthy donor was used as control. (B) Experimental schematic for the generation of ES followed by xenografting human skin onto NSG mice. (C) Representative photograph of ES and skin grafts on day 144. (D) Representative flow cytometry analysis and (E) graphical summary of $\mathrm{CLA}^{+} \mathrm{CD} 103^{+}$cells by live gated human $\mathrm{CD} 45^{+} \mathrm{CD} 3^{+} \mathrm{CD} 4^{+} \mathrm{CD} 45 \mathrm{RA}^{-} \mathrm{T}$ cells from skin grafts, spleen, and $\mathrm{ES}$ (3-5 weeks after skin grafting). Open and filled symbols denote samples derived from 2 different skin donors. Each symbol represents data from one recipient animal. (F) Representative flow cytometry analysis and graphical summary of expression of CD27, CD9 
and CD69 by live gated $\mathrm{CD} 45^{+} \mathrm{CD} 4{ }^{+} \mathrm{CD} 45 \mathrm{RA}^{-} \mathrm{CD} 103^{+} \mathrm{CLA}^{+} \mathrm{T}$ cells in the skin grafts, spleen, and ES 5 weeks after skin grafting (day 145 relative to ES generation). Significance determined by one-way ANOVA with Tukey's post-test for pairwise comparisons. (G) Experimental schematic for the generation of ES followed by adoptive transfer of $2.5 \times 10^{6}$ PBMC (autologous to the ES)/mouse into NSG mice. (H) Representative flow cytometry analysis and (I) graphical summary of $\mathrm{CLA}^{+} \mathrm{CD}_{103^{+}}$cells by live gated human $\mathrm{CD} 45^{+} \mathrm{CD}^{+}{ }^{+} \mathrm{CD} 4{ }^{+} \mathrm{CD} 45 \mathrm{RA}^{-} \mathrm{T}$ cells from spleen, and ES 25 days after PBMC transfer. Each symbol represents data from one recipient animal. Significance determined by paired $t-$ test. 